\title{
Beitrag zur Kenntniss der Schweinesenche.
}

\author{
Von \\ 1)r. Bleisch, \\ Kgl lireis-Physikus zu Cusel in Ober-Schlesien, \\ und Fiedeler, \\ Kigl. Kreis-I'hicrarzt zu Cosel in Ober-Schlesien.
}

Im 30. October 1888 wurden uns von dem Käsefabrikatuten Höumos zu Krzanowitz die halofaulen Lungen zweier nothgeschlachteten Schweine mit folgenden Angaben zur Untersuchung übergeben:

,Yor etwa zwei IEonaten kaufte ich auf dem Cosuler Viehmarkte ats verschiedenen Treiberherden 23 Schweine, unter welchen vier Wochen später Krankheitserscheinungen auftraten; die Anfangs in Husten und Athmungsbeschwerden, spitter ausserdem in Störung der Fresslust bestanden. Von diesen Schweinen habe ich vier Wochen nach dem Ankate sieben Stück verkauft und dafür aus meinem Bestande sieben Stück in demselben Stall untergebracht.

Sobald ich später an den Thieren gefuhrdrohende Krankheitserscheinungen bemerkte, habc ich dieselben zum Abschlachten verkauft, so dass ilus jenem Stalle nur drei Thiere eingegangen sind, während ich sechs Stück an den Fleischer verkauft und zwei zum eigenen Gehrauche nothgeschlachtet habe; von den letzteren stammen die zur Lntersuchung übergebenen Lungen.

Die Lungen der meisten geschlachteten Thiere habe ich gesehen und gefunden, dass sie zu gross und von derber, ,todter": Beschaffenheit waren."

Diese beiden Lungen zeigten folgenden Befund:

Lunge I. Volumen nicht vergrüssert, Pleuraüherzug im Allgemeimen glatt, rechter Hautlappen mit dem mittleren frisch verklebt; Oberfläche blassgelb, roth marmorirt. Vorder- und Mittellappen beiderseits und der rordere Theil des linken Hauptlappens derb, auf Fingerdruck nicht knisternd, grauroth; der rechte und linke Huuptlappen ausserdem ron kleinen, bis zeitschr. f. Hygiene. VI. 
hasehnussgrossen, derben Knoten durchsetzt. Schuittflïche dieser hepatisirten Theile und Knoten gleichmässig grauroth, feucht. Ans den Luftrührendurchschnitten entleert sich auf Druck glasiger, graugelb gefürbter, sehr zäher Schleim, aus dem hepatisirten Lungengewebe schmutzig graurothe, trübe, von Iuftblüschen freie F'lüssigkeit. Dic Lılltröhrenschleimhaut nicht geschwellt oder geröthet, die Bronchialdrïsen geschwollt, ant dem 1)urchschnitt fencht, ron miukigem Ansehen, griuroth, von kïsigen Herden durchset:t.

Innge Il. Sehr umfingrcich, durchweg knotig, derb, auf l'ingerdruck wenig linisternd. Pleuraübermg und Pericard nicht spiegelnd, mit leicht abstreifbarem, librin̈̈s'n Belage rersehen. F'arbe grauroth, stellenweise lleckig-dunkelroth. Der Jurehschnitt, theils grauroth, theils dunliclroth, wcist zahlreiche, theils grössere, theils kleinere, durch lufthaltige Parthieen ron einander getrennte Stellen auf, die, grauroth bis dunliclroth gefïrbt, sich derb anfühlen und auf Druck trïbe, granrothe, ron Juftbläschen freie Flüssigkeit entleeren. Aus den innerhalb dieser hepatisirten Stellen gelegenen Bronchialdurchschnitten entleert sich glasiger, gringelb gefäroter, sehr zäher Schleim. IJuftröhrenschleimhaut uicht geschwellt oder gcröthet. Bronchialdrüsen geschwellt, auf dem Durchschnitt mirkig grauroth, ron kïsigen Herden durchsetzt.

In den ron dem Gewebssaft dieser beiden lungen angelegten, mittelst l'uchsin gefïrbten Ausstrichprïparaten fanden sich zallreiche Stäbchenbacterien ron der verschiedensten Grösse und lorm.

Dieser anatomische Befund, zusammengchalten mit dem Inhalte der obigen Angaben des Besitzers der fraglichen Schweine, legte die Termuthung: ron vornherein nahe, dass es sich um eine ansteckende Schweinelirankheit handelte.

Behufs Feststellung der Krankheit sach ihrer Natur und Aetiolugie: cutschlossen wir uns deshalb zur Vornahme von Impfrersuehein und bacteriologischen Lintersuchungen, welehe; dil uns ein stetig wachsendes Material zulloss, einen grösseren Umfang annahmen, als wir von rornherein beabsichtigt hatten.

Wenn wir die Ergebnisse dieser Untersuchungen v(rïffentlichen, so müssen wir gleichzeitig eine gewisse Rücksjchtnahme für uns in Anspruch nehmen, da uns bei unseren Arbeiten nicht die reichen Mittel rin's bacteriologischen Instituts zur Verfïgung standen und unsere drbeitszeil natırgemäss, eine ungeregelte und beschränkte war; andererseits glauben wir uns zu dieser Veröffentlichung berechtigt, weil wir uns bewasst sind, dadurch, - dank der Reichhaltigkeit und Frische des uns zur Verfügung stehenden Lintersuchungsmaterials - zur Vurvolständigung der noch 
immer mangelhaften Casuistik beizntragen, und weil die grosse Nähe des seuchenherdes es uns möglich machte, über den noch nicht genügend aufgeliärten Modus der Weiterverbreitung der Krankheit nicht ganz unl'uchtbare Untersuchungeul anzistellen.

Der Grang unserer Arbeiten wurde im Allgemeinen durch den luhalt der vorzüglichen Sch ïtz'schen Arbeiten bestimmt.

'/ur' Hrziclung von Reinculturen des von uns vermutheten Kirankheitserregers bedienten wir uns nicht nur des Koch'schen Plattenverfahrens, sondern gleichzeitig; nach Vorgang ron Schütz, der directen Verimpfung des fraglichen Materials auf Kaninchen und Hühner in der liwägung; diss es schwierig werden kïnnte, unter deu zahlreichen auf der Platte zu urwartenden, fremden Colonieen die richtigen, ihrer form und ihrem Wachsthum nakh uns ja noch unbehimnten pathogenen Colonieen heratuszulinden.

\section{Versuchsreihe.}

Im 30. Uctoher ls8s wurde Kaninchen Ne. 1 in folgender Weise geimptt:

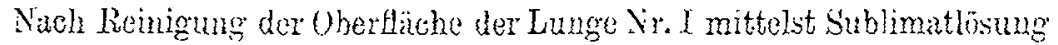
(1:1000) wurde mit cincm ansagrglühten Iless'r cin senkrecht zur Oborfläche stehender schnitt in einen linoten der lunge und mit einem zweit'n ansgeglïhten IIesser ron der entutandenen Schnittlläche aus ein anderer, zu dem ersten in rechtem Winkel stehender Schnitt gemacht. Aus diestr zweiten Schnittllïche wurde mittelst ausgegliihter Pincette ein Gewolsstrickiben herausgehoben und in rine am Rücken des Kaninchons mil alusgegiühter Schecre angolegto Halttasche geschoben.

Ein in derselbeu Wrise gewonnemes Gewebsstïckchen wurde in einem mit sterilisirter, durch mïssiges Erwärmun flüısigg gemachter Fleischpeptongratine verseh'nu Reagensglïschen mittelst ausgeglühter Platinnadel verrieben; ron diesem Glischen wurde ein zweites, ron dieserm rim drittes mittelst je zehn Oesen geimpft, der Inhalt in je cin" sterilisirte Crlassohale ausgregossen und nach dem Erstarren der Gelatine die Sohalen bei Zimmertemperatur gehalten.

Im Morgen des 31. Oetober wal das Kaninchen trimrig und athmete"

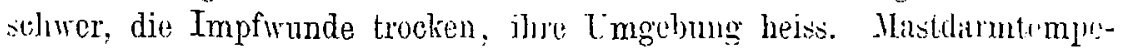
ratur $+1 \cdot 2^{\circ} \mathrm{C}$.

Im 1. November war der 'T'od eingetreten.

Sectionsbefund: In der Impfistelle ist das Linterhautbindegewehe und das Juskelgewebo eiterig durchtränkt, die Lympligefüsse mit eiterigem Rahm prall getïillt, dic Lymphdrüsen der Flankenfalten bohnengross, ihro Schnittfliche markig, mit dunkelrotlen Elecken durchsetat, die Submaxillar- 
drüsen markig geschwellt. In der Brusthöhle blutige Flüssigkeit, die Lungen ödematös, ihr Ueberzug spiegelnd, ihre Schnittfläche hellroth, ihr Gewebe überall lufthaltig. IFerzohren, und -Kammern mit weichgoronnenem Blute gefiillt. Milz leicht geschwollt, ihre Pulpa reichlich, ihre Zeichnungr undeutlich. Lcber braunroth, glatt, an der Obertläche mit kleinen Ecchymosen besetzt, auf dem Durchschnitt sehr blutreich. Magenschleimhaut nicht voränılert, Schleimhaut des Dünndarms schwach geröthet, dic der Blinddarmklappe nicht verändert, ebenso wenig die des mit breiigem Inhalte gefiillten Dickdarmes; die Peyer'schen Plaques kaum erkennbar.

In den Ausstrichpräparaten, die aus dem rahmigen Liter der Impfstolle, aus dem Gewebssafte der Leber und Milz angefertigt und theils mittelst Gentianaviolett, theils mittelst F'uehsin gefürbt wurden, fanden wir ausschliesslich eine ungeheure IIenge kleiner, jedoch verhältnissmässig. breitur, an den Enden abgerundeter, glcichmässig gefürbter Bactericn, welche im hohlen Objectträger sich unbewoglich erwiesen.

In der Milz dieses Kaninchens wurde in der gleichen Wuise, wie oben besclurieben, cin Doppelschnitt angelegt und mit geglïhter Oese cin 'Tropfen Milzblut in cinem mit sterilisirter, alkalischer Brühe armirten liengensgläschen verthcilt.

Ein in derselben Weise, wic oben geschildert, gewonnenes Gew(1)sstückchen der Hilz wurde zur Infiction von Gelatineplatten benutzt, wobei genau in der früher geschilderten Weise verfahren wurde.

Ferner wurde unter den gleichen Torsichtsmassregeln cine mit dem Gewebssaft der Lunge benetzte, vorher ausgeglühte Platimladel in ein mit sterilisirter:, neutraler Hleischpeptonagar rersehencs Gliischen eingestochen und endlich je einem Kaninchen ein Gewebsstückchen der Wilz (Kaninchen 4) bezw. ein solches der Lunge (Kaninchen 5) in cinc am Ohr angelegte Hauttasche geschoben.

Beide Jíaninchen waren am 2. November gestorben. Der Sectionsund der bacteriologische Befund stimmten mit dem oben geschilderten des Kaniuchen 1 überein.

Die Lntersuchung der ron der Schweinelunge $1 \mathrm{am} 30$. October angelegten Platten führte zu keinem Ergebnisse, sei es, weil dio vou uns benutzte Fleischpeptongrelatine, wie sich später für einen Iheil derselben herausstellte, nicht genügend neutralisirt war, sei es, weil wir der grossen Menge verschiedener, zum grossen Theil der I'üulniss angehörigen Colonicen in nnserer Unkenntniss über die Wachsthumseigenthümlichkeiten der vou uns gesuchten Bacterien, welche zudem in der Schnelligkeit des; Wachsthums woit hinter den gewöhnlichen Bacterien zurückstehen, rathlos g'egenüberstanden.

Besser erging es uns mit den aus Kaninchen 1 am 1. Norember angelegten Platten, die wir; um Terunreinigungen bis zur entscheidenden 
Cntersuchung auszuschliessen, erst am 10. November untersuchten. Hier waren in allen drei Platten eine entsprechende Zahl unter einander durehaus sich gleichender, die Gelatine nicht rerflüssigender Colonieen genachsen, welche in der der zweiten Verdünnung angehörigen Platte winzig kleine, unter dem Mikroskope bräunlich -gelbe, runde, fein granulirte und mit. concentrischer Ringzeichnung rersehene Conglomerate darstellten.

Die von diesen Colonieen gewonnenen Ausstrich- und Klatschpräpurate reigten nach Fuchsinfürbung unter Anwendung von 'Leiss' Apochromal Oelimmersion 1.30, Apert 2.0 und Compens Ocular Nr. 8 theils ganz kurze, aber breite und deshalb mikrokokkenartig geformte, theils lingere. hreite, aber immer mit al)gerundeten Enden versehene Bacterien, dancben solche, die nur an den Enden gefärbt waren und sich deshalb wie zwei, durch schmale I,cisten mit einander verbmidene Milrokokken darstellten, theils endlich entsprechend dicke, längere Fülen von oft geschwungener l'orm. Wir bemerken, dass sich alle diese rerschicdenen Gebilde in jeder einzelnen der vielen von uns untersuchten Colonieeil vorfinden.

Die am 1. November inficirte und bei lBruttemperatur gehaltene Brühe zeigte sich :um 3. Tovember stark getrübt und enthielt, wie gefïrbte Ausstrichpräparate machwiesen, eine Reincultur ron Bacterien, die ovoide I'orm. bexassen und bei bald grösserer, bald geringerer Lünge zum Theil ein Imgefürbtes Mittelstück aufwiescen.

Der am 1. Norember angelegte dgarstich zeigte am 11. Norember eine bis zu seinem muteren Ende reichende weisse Farbe; um den Jinstich herm befand sich an der Oberfliche ein trübgraner, durehscheinender, trockener Wall von geringer Ausdehnung. Gefïrbte Ausstrienpräpirate, von diesem Wall entnommen, wissen eine Reineultur ron Bacterien auf, deren frorm mit derjenigen übereinstimmte, wie wir sie in den Plattenculturen, in der Brühe nnd auch in Organen dor Kaninchen 1, 4 und 5 machgewiesen hatten.

Um den pathogenen C'harakter dor ausserhalb des Körpers gezüchteten Bacterien nachzumeisen, wurden am 10. November zwei der in der zweiten, ron Kaninchen 1 stammenden Verdünnungsplatte gewachsenen, mit concentrischen Ringen versehonen Colonieen mittelsi, geglühter Platinnadel gefischt und diunit abermals ein Kaninchen (Nr. 16) und ein $\mathrm{Huhn}$ (Nr. 3) unter Beobachtung der beschriebenen Torsichtsmassregeln, ersteres am Ohr, letzteres unter dem Flügel geimpft.

Huhn 3 war am 12. November todt.

In der Impfstelle fand sich starke, entzündliche Reaction; an den inneren Organen liel uns, abgesehen ron Rïthung der Dünudarmschleimhaut, makroskopisch nichts auf. Ausstrichpräparate, rom Gewebssuftr rerschiedencr Organe angefertigt, zeigten gefärbt ausserordentlich zahlreich 
oroide Bacterien der oben beschriebenen Form, rielc daron mit ungefiubtem Hohlraume versehen.

Kaninchen 16 starb am 7. December.

Sectionsbefund: Sehr abgemagerter Leichnam, an der Impfstelle geringe entzündliche Reaction neben einzelnen schwach mit Fiter gefüllten Lymphstrüngen; Axillardrüsen geschwellt, im Herzbeutel geringe Menge rüth. licher I'lïssigkcit, Lungen normal. Milz leicht geschwellt, Leber gesehwelli, glatt, im Allgemeinen dunkelbraunroth, an der Oberfläche zahlreiche, theils zweigförmige, theils rundliche, weissgell gefärbte Stellen, ebenso auf dem braunrothen Durchschnitt, welche durch schmierige Massen gebildet worlen. An Nagen und Darm nichts Auffülliges.

In den von dem Inhalt der Tymphstränge an der Impfstelle, rom Gewehssaft der Leber, Milz, Tangen und von der Herzbentelftüssigkeit. ingefertigten und mit Fuchsin oder Gentianavioleti. grä̈rbten Prïpariten finden sich durchweg sehr wenige der beschriebenen ovoiden Barterien. aher diese ausschliesstich.

Wegen des von dem bisher Gesehonen in der J)aner abweichenden Kirankheitsverlaufes und des ebenfalls abweichenden inatomischen und bacteriologischen Befundes wurde am 7. Inecember:

a) aus dem Her\%blute eine Brühecultur angelegt, in welcher sich nach einigen I'igen ausschliesslich ovoide Bacterien rorlanden.

b) Kaninchen 36 mittelst eines kleinen Jeber- nnd Herstïghehens: des Kaninchens 16 in der oben angegebenen trt am Rïcken geimpft. Dasselbe starb am 15. I)ecember.

Sectionsbefund: Impfwumde verklebt: um dis Impfstelle herum ist das Unterhauthindegowebe in der Ausdchung einos fiünfmarkstïckes eiterigr infiltrilt. An Terz und Lungen nichts Auffälliges, Mil\% Tricht geschwollt. J'ulpa weich. An Nieren und Leber trïho Sohwellung.

Ausstrichpräparate des Eiters der Impfstelle weisen ein buntes IBartreriengemisch ohue Torwalten einer besonderen f'urm nach.

Ausstrichpräparate rom Gewebssaft der Teber, Nieren und Mlilz weisen nicht sehr zahlreich Bacterien inf, welche jedoch sümmtlich in der Form und Grösse mit den beschriehenen ovoiden Bacterien übereinstimmen.

Damit wurde die erste Versuchsreihe abgeschlossen. Das Schem: derselben, sowie dio der nachfolgenden Versuchsreihen befinden sich aul S. 450.

Wir hemerken dazn, dass der Uebersicht wogen in diesem Sohema nur dicjenigen Impfthiere, Platten, Stiche und Brïheculturen Aufmame gefunden hiben. bei welchen ein poxitives lirgebniss przielt wurde. 
Am 31. October wurden bei einem hicsigen F'leischer fünf aus dem inficirten Stalle stammende Schweine - Ir. I bis V - gesehlachtet, von iuns geöffinet und untersucht.

Zwei von ihnen; die anscheinend am schwersten erkrankt waren, boten hei Tebzeiten folgende Krankhcitserscheinungen:

Schwein I: Bastard, Borg, fünf Nonate alt, mittelmässig eruährt, Husten und geringe Ithembeschwerde, Mastdarmtemperatur 40.40, Fresslist normal.

Schwein II. Bastard, Sau, sieben. MIonate alt, geringer Husten, mïssige Frnïhrung, 39.4 Mastdarmtemperatur, Fresslust normal.

Beide Schweine wurden in folgender Weise ron uns geiffinet und untersucht.

Dic Haut der Bauchfläche wurde mit Sublimatlösung $(1: 1000)$ ab)gewaschen, alsdann mit geglühtem Messer der Bauchsehnitt gemacht und mit einem zweiten, ausgeglühten 3Lessor die Bauchhühle eröfnet, woraul" die Herausnalme der Milz mit abermals ansgeglühtem Messer erfolgte. Sach Fintfernmg der Fingeweide und Durchschneidung des /werchfells wurden die Tamgen heransgenommen.

Jil\% und Limgen wurden unmittelbar nah der Herausnahme in Fliesspapier, welches mit der genannten Sublimatlïsnng getrünlit war, eingonickelt und in sterilisirte gliisorne Doppolschalen getrenut gegeben.

Diw übrigen drei Schweine (III, IT und V), ebenfalls der veredelten Saundrace angelıörend und nicht über acht Monate alt, welche angeblich hei Tubzeiten keine Kraukheitserscheinungen gezeigt hatten. wurden ohne diest: Vorsichtsmassregeln geöftnet.

Seetionsbefund: Schwein I. Ifaut und Lnterhantzellgewebe nicht verändert, ebenso wenig die ïbrigen Organe, wie besonders die Schleimhant des Dünn- und des mit Fïces gefüllten Dickdarmes, mit Ausnahme der Lungen und zwar: Brustfelle glatt, Vorderlappen beiderseits grauroth hepatisirt. Mittellappen links im vorderen Theile heparisitt, irn hinteren lufthaltig. Mittellappen rechts enthält dunkelkirschrothe, derber auzufühlende Felder, die durch lufthaltige hellrothe Stellen yon einander getrennt sind. Linker Hauptlitppen von hepatisirten, härteren, granrothen Stellen durchsetst. Rechter Hauptlappen mit einzehıen härteren Knoten durehsetzt. Anf der Schnitttäche einige käsige Stellen in den Vorderlappen. Bronchialdrüsen markig geschwellt und mit kïsigen Merden durchsetat. Ius den feinsten Bronehialdurchschnitten injerhalb der hepatisirten Stellen quillt auf Druck glasiger. graugelber, äusserst zäher Schleim.

Bei don übrigen Iungen (Schwein II bis T) waren nur die Torderlappen, und zwar besonders an ihrem unteren Theil, felderwoise, grauroth hepatisirt. Eine Lunge zeigte ausserdem frische, fibrinöse Auflagerungen. uuter denen sich in den Maschen des subpleuralen Gewebes punktförmige Blutungen befanden. Der Befund der Bronchialdrïsen gleicht dem ron Schwein I. 
In den rom Gewebssaft der hepatisirten Stellen dieser Iumgen ingelegten Ausstrichpräparaten fanden wir lieine Bacterien.

\section{Versuchsreihe.}

$\Lambda \mathrm{m}$ 31. Octobcr wurde mit einem den hepatisirten Theilen der Iunge des Schwein I nnter den früher beschriebenen Vorsichtsmassregeln entnommenen Gewebsstückchen Kaninchen 2 am Rücken geimpft.

Am 1. November zeigt sich dasselbe traurig, athmet angestrengt, dic Impfstelle ist heiss und geschwellt, MIastdarmtemperatur: 40.9.

Am 4. November grosse Mattigkeit, Schwïche im Kreuz, Mastdarmtemperatur $40 \cdot 6^{\circ}$.

Am 5. November stinkende Durchfirlle.

Am 6. November Iod.

Sectionsbefund: Impfwunde trocken verklebt, um die Impfstelle herum in weiter Ausdehnung das Unterhautzellgewebe in eine derbe, dicke, weisse Uasse vorwandelt; von hier aus führen dicke, woisse Lymphstrünge nach den nächsten Lymphdrüsen hin. Lungen hellroth, auf der Schnittläche rothHeckig, Leber und Milz geschwellt.

In den Ausstrichpräparaten der Mil\%, Jeber, Tungen, des Her\%blutes und besonders des rahmartig infiltrirten Bindegewebes der Impfstell ansserordentlich zahlreiche, zu kleinen Haufen zusammen liegenle, oroido Bacterien von dem früher beschriebenen Aussehen.

Unter Beobachtung der früher angegebenen Vorsichtsmassregeln wuritn am 7. November von Organtheilen des Kaninchen 2 geimpft:

a) Kaninchen 10 mit Herzblut am Obre,

b) Kauinchen 11 mit einem Milzstückchen am Ohre.

Beide Kaninchen waren am 8 . Yorember todt und zeigten den Sectionsbefund ron Kaninchen 1.

In den ans Iseber, Hilz, Blut und der Impfstelle stammenden Ausstrichpräparaten fanden sich die beschriebenen ovoiden Bacterien in grosser Menge.

Von Kaninchen 10 wurde Kaninchen 12 in der früher angegebenen Weise am 9. November geimpft. Dasselbe starb am 11. Norbr. und zeigte bei der Leichenoffnung denselben Beftund wie Kaninehen 16. In den ron einzelnen Organen, besonders aus den embolischen Herden ¿ler leber stammenden Ausstrichpräparaten fanden sich sehr zahlreich und ausschliesslich die oroiden Bacterien ror.

Ton Kaninchen 12 wurde:

a) am 11. November Huhn 4 unter dem Flügel mittelst eines Stückchens aus einem embolischen Lcber-Herde;

b) am 13. Nor. Kaninchen 17 am Rücken mit Herzblut geimpit. 
Huhn 4 starb am 22. November.

Sectionsbefund: Die Impfstelle zeigte geringe Reaction, der übrige Sectionsbefund war negativ.

In den ans verschiedenen Organen angelegten dusstrichprïparaten finden wir lediglich die ovoiden Bacterien sehr zahlreich ror. Fis wurden:

a) mittelst eines I cberstückchens des Huhn 4 am 22. November drei F'leischpeptongelatine-Platten in der früher beschriebenen Weise angelegt.

In diesen Platten wuchsen im Verlanfe der nïchsten Tage wicderum die oben boschriebenen, mit concentrischen Pingen versehenen Colonicen. deren Bacterien dieselbe Form zeigten, wie die ron Kaninchen 1 gewalchsenen Culturen.

b) am 22. November wurde Kaninchen 26 mittelst einos Her",stückchens ron Huhn 4 auf dem Rücken geimplt.

Dasselbe starb am 28. Norember.

Sectionsbefund: Impfwunde verklebt, an der Impfstelle ist das Bindegewebe an einer thalcrgrossen Stelle citorig infiltrirt, leber geschwellt und mit denselben embolischon Merden durehset $\%$, wie bei Kaninchen 16: Milz leicht geschwellt, Itungen rechts lufthaltig, rothfleckig, links derb, auf der Schnittfläche roth marmorirt, auf Druck quillt fester Schleim ans den Bronchien.

In den von dur Impfstelle, dem Blut und den Organen angolegten Anstrichpräparaten ansserordentlich zahlreich unsere oroiden Bacterien.

Aus dem Herzblute des Krianinchen 26 wurden am 28. Tor. angelegt:

1. drei Fleischpeptongelatine-Platten, welehe nach Fraluf einiger Thage charaktcristische Culonieen zeigten,

2. eine Stichcultur in Fleischpeptonagar,

3. eine Sticheultur in Fleischpeptongelatine.

Beide Stichculturen wuchsen in der früher geschilderten chitraktoristischen Weise und bestanden, wie nach der dnfurtigung gefärbter Ansstrichpräparate sich zeigto, lediglich aus den ovoiden Bicterien.

Kiduinchen 17 war am 1 . December todt.

Sectionsbefund: Starke Abmagerung, reringe Reaction an der Impfstelle, an derselben einzelne, eiterig infiltrirte Lymphsträngc: in der Leber wiederum, wie beim Kaninchen 16 und 26 zahlreiche embolisehe llorde.

In den Ausstrichprïparaten nicht allzu zahlreich oroide l3acterien.

Ius dem Herzblute ron Faninchen 11 wurde Huhn 2 am 8. Nór. unter dem linken Flügel geimpft. Diksselbe war am nüchsten Tiage traurig and zeigte geringe Athembeschwerde. 'Temperatur 42.5, welch" Hrscheinungen bach einigun 'Tagen rerschwunden waren. Das Huhn blieb lebendig. 


\section{Versuchsreihe.}

Am 31. October wurde ans der Milz des Sehwein II unter den früher angegebenen Vorsichtsmassregeln Kaniuchen 3 geimpft.

Am 1. November war dasselbe weniger munter, 'lemperatur 39.6. geringe Athembeschwerden, Impfstelle heiss, empfindlich.

Am 2. November Temperatur 40.6. Am 3. November Tod.

Sectionsb ofund: Impfwunde verklebt, Unterhautzellgewebe im Umfange cines Markstückes citerig infltrirt. Eiterige Lymphangitis an der Impfstelle, Lymphdrüsen der Flankenfalten markig geschwellt.

In den Ausstrichpräparaten der Impfstelle und der inneren Orgime zihlreiche, zum Theil mit Hohlrïumen versehene vroide Bacterien.

17 Stmndeu nach dem Tode, also am 4. November, wurden mittelst eines Milzstïckchens ron Kaninchen 3 geimpft:

1. Kaninchen 8 am rechten Obre,

2. Huhn 1 unter dem linken Flügel.

Kaminchen 8 war am 5 . November todt.

Ausstrichpräparate der Organe zeigten sehr zahlreich die ovoiden Bacterien.

Mit dem Her\%blut des Kaninchen 8 sofort beschickte alkalische Brühe war am 9. November bei 'immertemperatur trübe geworden und reggte in Ausstrichprïparaten Reincultur unserer ovoiden Bacterien.

Huhn 1 starb am 17. November.

Ausstrichprïparate der Organe zeigten eine geringe Anzahl unserer woiden Bacterien, aber diese anch nur allein.

Im 17. November wurden von Hohn 1:

1. drei ans Leberblnt inficirte Fleischpeptongelatine-Platten angelegt. in welchen nach einigen Tagen die früher beschriebenen (olonien nuscrer woiden Bacterien wuchsen.

2. Kaninchen 20 mit Teberblut am Rücken geimplit.

Dieses war an 22. November todt.

Seine Organe rejgten in Ausstrichpräparaten norenige unserer Bacterien, aber auch nur diese allein.

Im 19. Norember wurden mittelst pines Lungenstückchens rom Huhn 1 geimpft:

1. Hubn 7 unter dem Flägel.

Tou am 17. December.

Sectionsbefund: Negativ bis auf den des Zwölffingerdarms, dessen Schleimhaut braunroth und geschwellt war, and bis auf deutliche Sehwellung des Solitärfollikel. 
In len aus der Lunge, dem Kinochenmirk und dem Blute stammenden Ausstrichprïparaten unsere ovoiden Bacterien in geringer Kahl, in der Leber wurden kine gefunden.

2. Kaninchen 21 mit einem Tungenstückchen am Rücken.

Tod am 25. November.

Sectionsbefund: Starke Abmagerung. An der Impfstelle das Luterhautbindegewebe eiterig infiltrirt. Rechte Lunge gleichmässig, linke fleckigroth. Innerhalb dieser hämorrhagischen Stellen halbhirseliongrosse, tuberkel:̈hnliche, die Pleura vorwölbende Knötehen.

Aus diesen Kü̈tchen angefertigte, mit $\mathrm{Zi}$ el'scher Fuchsinlösung gefärbte und nachtrïglich entsprechend entfärbte Ausstrichpräparate zeigen keine Tuberkelbacillen. Der Impfstelleneiter enthiclt ebenso wie lieber und Blut zahlreich unserc ovoiden Bacterien.

Aus dem Herzblut des Faninchen 21 wurden am 25. Norember drei Pleischpeptongelatine-Platten angclegt, in welchen nach einigen 'ligejl dis: Colonieen unserer oroiden Bacterien wuchsen.

Mittelst eines ron Kaninchen 21 entnommenen Iungenstückchens wurle am 25. Tovember Kaninchen 25 am Rücken geimpft.

I'od am 2. Januar 1889.

Sectionsbefund: An der Impfitelle keino Resetion: auch sonst keine Verïnderungen an den inneren Orgranon.

In den Ansstrichprïparaten der inneren Organe waren keine Bacterien \%u linden.

Wir bemerken hierzu, dass wir am 2. Jamuar 1889 aus der Mil?. des Kaninchen 3 und der Leher des Kaninchen 20 je drei Fleischpepton-

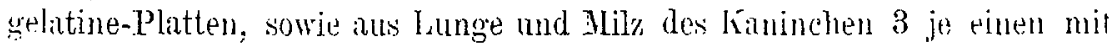

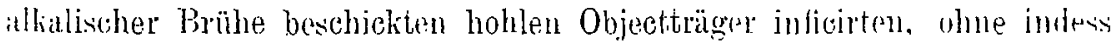
lanit zu einem jusitiven Ergebnisse zo konmen.

\section{Versuchsreihe.}

Im 2. November wurde aus einem unter den früher angegebonen Vorsichtsmaassregeln angelegten Doppelquerschnitte eines hepatisirten Theiles der Iunge des Schwein III, welche noch keinen Verwesungsgeruch zrigte, geimptt: Kaninchen 6 und Kaninchen 7 . Beide waren am 3. Norember todt.

Wegen ILangel an \%ait wurde nur hininchen 7 geöffinet. welchts ansser eiteriger: Infiltration der Impfstelle keinen anffallenden Sutionbefind zeigte.

In den Ausotrichprïparaten aus Milz und Teber ansserordentlich zahlreich oroide Bacterien, besonders aber in dem Eiter der Impfstelle. 
Drei aus der Milz des Tíaninchen 7 inficirte FleischpeptongelatinePlitten rerdarben in Folge von Schimmelbildung.

Am 9. November wurden in einer hiesigen Fleischerei viederum 7 ans dem inficirten Still stammende Schweine VI-XII (die letzten), welche bei Jubzeiten geringen Husten und schlechte Frnïhrung gezeigt hatten, geschlachtet.

Dieselben gehörten, wie alle früheren, der veredelten Isundrace an und waren 5 bis 8 Monat alt.

Schwein VI und VII wurden ron nus unter den früher beschriploenen Vorsichtsmaassregeln geöfnet.

Scctionsbefund: Schwein VI. An dor Imenfäche des rechten UInterschenkels ein 50-pfennigstüekgrosses Geschwïr mit zernagten Ründlen; Grund und Ränder hart. In der Richtung nach der Flankenfalte hin im Verlaufe der Lymphgefässe cine Roihe von drei kleineren, sonst ebenso beschaffenen Geschwüren. In der entgegengesetzten Richtung in der Nïho des Sprunggelenks eine halbhïhnereigrosise, fluctuirende Cyste, mit Jauche gefiillt und mit jauchigen, missfarbenen fetzigon Wänden versehen. Rechte Leistendrüse zwoimal so gross wie dic linke, auf der Schnittfïche derhe und zahlreiche kïsige Tlerde imerhalb des markig geschwellten Gewoloss anfweisend.

Vorderlappen der Lungen beiderseits inselförmig grauroth hepatisirt, die grossen Bronchien mit feinblasigem rothen, die feinen zu den liepatisirten Stellen führenden mit graugelhem, grlasigon zähen Schlcim gofüllt. Bronchialdrüsen markig geschwellt, geringer Milztumor, der gefiillts Dickdarm nicht verändert.

In den aus dem glasigen. Bronchialschleim, aus dem Herzblut, dem Milzsaft, dem Bronchialdrüsenkïse und aus den geschwellten Leistendrüsen imgefertigten Ausstrichpräparaten fanden sich sehr zahlreich unsere ovoiden Bacterien vertreten, besonders zahlreich im zähen, graugelben Brochialschleim, in geringer Anzahl in den grauroth hepatisirten Stellen.

In den gehärteten Schnittpräparaten der hepatisirten Theile der I muge fanden sich zahlreich in Haufen liegend die gleichen Bacterien.

Der Jungenbefund der Schweine TII lis XII wich fin dom des Schwein VI nicht wesentlich ab.

Auch der Bacterienbefund war derselhe.

\section{Versuchsreihe.}

Als Ausgangsobject diente die unter den früher beschriebenen Vorsichtsmaassregeln entuommene, geschwellte rechte Iteistendrüse des Schwein YI. 
Einem in der gewohnten Wuise in derselben an 9. Norember angulegten doppelten Querschnitt wurde cin liäsetheilchen entnommen und

1. dem Kíaninchen 13 unter den Rücken gebracht,

2. mit einem gleichen Theilchen drei Fleischpeptongelatine-Platten inficirt, in welchen nach einigen 'Tagen die früher geschilderten, später mit cuncentrischen Kingen versehenen Colonieen heranwuchsen.

Kaninchen 13 war am 11. November todt.

Der Sectionsbefund wies neben eiterige: Infiltration der Impfistelle röthliches 'lranssudat in der Brusthöhle und dio früher beschriebenen, umbolischon Herde in der Leber aut.

In den Ausstrichpräparaten des Impfistellen-lijters, des 'l'russudates und der Leberemboli wiederum sehr zahlreich und allein unsere ovoiden Bacterien vorhanden.

Mit einem Leberstückchen des Kaninchen 13 wurde im 13. Nuvember Huhn 5 unter dom rechten F'lügel geimpft. 'Tod am 14. Norember.

Sectionsbofund: An der Impfstelle starke Reaction, Leber geschwellt, braumroth.

In den aus Tebergewebssaft, Herzblut and Imptstelleneiter ingefertigten Ausstrichpräparaten sehr zahlreich unsere ovoiden Bacterien.

Aus dem Herzblut des Huhn 5 wurden am 11. November drei Fileischpeptougelatine-Platten angelegt, in welchen am 20. Norember sich dio charakteristischen Colonieen unsercr oroiden Bacterien gewachsen fanden.

Ius ciner in der 2. Yerdüunungsplatte gewachsenen Colonie rude im 20. November ein aus alkalischer F'leischbrühe bestehender hängender Tropten im hohlen Objecttrïger inticirt, welcher, trotzdem er bei Bruttemperatur gehalten wurde, steril blieb.

Im 25. Norember wurde aus einer Colonie derselben Plath cinc Stichcultur in Fleischpeptongelatine angelegt, welche am 2. Teecmber dals charakteristische Wachsthum unserer ovoiden Bacterien reigte; Ausstrichpräparate crwiesen die Reincultur.

Am 2. December wurde aus dieser sticheultur:

1. ein Glïschen alkalischer Bouillon inficirt, welche nach einigen Tagen getrübt war und eine Reincultur der oroiden Bacterien enthielt.

2. Kaninchen 28 am rechten Ohr geimpit. Dasselbe war am 3. Devember todt.

Sectionsbefund: An der Tmplistelle Schwellung und eiterige Infiltrition des Bindegewebes, in der geschwellten Leber sebr zahlreiche embolische Herde.

Die Ausstrichpräparate ergaben den ausschliesslicheu Befund unserer vroiden Bacterien. 
Aus Herablut and Iebergewebssaft wurde je eine Stichoultur in lileischpeptongelatine angelegt.

Am 6. December wurde aus der Stichealtur rom 25. November dinc Brühecultur angelegt, welche bei einer Temperatur ron 20 bis $35^{\circ}$ (.. gehalten wurde. Am 10. December war dieselbe trïb und enthielt eine Reincultur unserer ovoiden Bacterien.

Von dieser Brühe wurde am 10. December 1;, Pravazische S'pritze roll dem Kaninchen 35 in dic rechte Lunge gespritat. Am 11. Jecember war Kaninchen 35 todt.

S'ectionsbefund: In der Brusthöhle röthliches l'ranssudat, Pleura glatt, linke Inunge intensiv roth, mit kleinen holler gefurbten stollen, lufthaltig: rechte Lunge hepatisirt, grauroth. I cichte frische Pericarditis, J eher sohr gross, OberHïche mit zahlreichen, bis erbscngrossen, wrspringenden, gelblichen Knötehen bosetat, ebenso die Schnittfäche. Milz star'k goschwellt, J'ulpa reich überquellend, trübe Schwellung' der Nieren.

In allen Organen. sowie im Knochennark mind Transsudal sehr rahlreich unsere oroiden Bacterien. In Schnitten der gehärteten Leber vehi zahlreich und allein unsere oroiden Bacterien zwischen den Leber\%elten, zum 'l'heil in grossen Haufen zusammenliegend.

Ius derselben von Huhn 5 am 25. Tovember angelegten Brühecultur, welche sich rein erhalten hatte, wurde am 3. December Intplschwein 2 neben der linken Schulter mittelst $3 / 4$ einer Prar rat sehen spritze subcutan inficirt.

lirankengeschichte des Impfischwein 2

Den 4. Decomber. Ist traurig, steht zitternd da, frisst aber; Haut iiber der Impfistelle warm und schmerzhaft, nicht roth. Temperitur -1.7 .

Den 5. December. Ist munterer, frisst, Impfstelle weniger schmer\%halt. T'emperatur $39 \cdot t$.

Den 8. December. Jst traurig, zittert, stöhnt viel. geht mit krummem Buckel unter Schonung des linken Hinterschenkels; Leib sehr aufgetrieben, gespannt, auf Druck sehmerzhaft, Durchfall. Temperatur 39.8.

Den 9. December. Der linke Hinterschenkel wird grar nicht gebraucht, ithembeschwerden. Temperatur $39 \cdot 6$, sonst wie am Jage zuror.

Den 10. December. Lahmheit beider Hinterschenkel. Beide Sprunggrcleuke geschwollen, hart, heiss, auf Druck schmerzhaft.

In die Haut über der kindorfaustgrosson Impfgeschwulst wurde atm 16. December mit geglühtem Messer ein Einschnitt gemacht, alus dem ödomatös geschwellten Gewebe miftelst gegiühter Platinnadel cin Tröpf́chen Gewebssaft entnommen und dieses auf einem Objectträger ausgestrichen. Dieses Präparat entbielt eine mendliche Zahl mscrer ovoiden Bacterien.

Den \&. Tebruar 1889. Das 'Thier ist munter, hnstet nicht, frisst. Impfgeschwulst bis aut einen kleinen Rest verschwunden, ïber welchem die Maut eine grosehengrosse Narbe zeigt. Die Geschwulst an den Sprung- 
gelenken fast verschwunden; dagegen sind die Vorderknice geschwollen und krumm. Gespannter Gang auf beiden Vorderschenkeln.

Nach dem verspäteten Bericht der Wärterin soll die Geschwulst vor ctwa 14 Tagen aufgegangen scin und bis vor Kurzem greeitert laben.

Am 2. März 1889 wurde ätusserer Gründe wegen Impfschwein 2 geschlachtet.

Sectionsbefund: Abgemagerter Leichnam, kein Hautölem, keine Hautverfïrbungen. An der Impfstelle eine ungefïhr 1 cin lange, lineare, rothbriune, verschiebliche Narbe. Beim Binschneiden daselbst gelangt man auf eine dicht. unter der Haut liegende, erbsengrosse, mit gelbgrünem, derbem Käse gefüllte Cyste, deren Wandung glatt und weisslich grau ist. Die Sprunggelenke deutlich, die Vorderkniee weniger verdickt; bei der Eröffnung derselben zeigte sich das um die Gelenke liegende Bindegewebe, sowie die Gelenkbänder verdickı, die Gelenkflüchen unverändert. Das Knochenmark der an dic Gelenke anstossenden Röhrenknochen ist weich und schmutzig-roth. Käsige Verïnderumgen nirgends vorhanden. Lungen, Brustfell und Pericard vollständig normal. Bauchfell verdickt, weisstichgrau, die Darmschlingen unter einander und mit der Bauchwand z. Th. mittelst weissgrauer, bindegewehiger Strüuge irrwachsen. Milz nicht vergrössert, derb, braunroth auf dem J)urchschnitt deutlich gezeichnet. Pulpa trocken. Nieren und Leber normal. Magen enthält flüssigen Speisebrei. Magen- und Darmschleimhaut normal. Fe yer sehe Plaques, insbesondere in der Nähe dor Ilencoecal-Klappe, obenso wie die Mescnterialdrüsen vergrössert.

In den Ausstrichprïparaten des Knochenmarkes, der Gulenkflüssigkeit und der inueren Organc keine Bacterien, in denjenigen, welche ans dem Inhalt der an der Implistelle befindlichen Kïlsecyste angefertigrt wurden, sehr zahlreiche kokken. Ton der aus dem Gewebssaft der Milz, der Leber; der Bronchialdrüsen, der Hesenterialdrüsen and dem Käse der erwähnten Grste angelegten l'leischpeptongelatine-Platten blieben sämmtliche steril bis auf die letzten, ans dem Kï̈se augelegten, in welohen in sehr zahlreichen Colonieen lediglich eine die Gelatine langsam rerflüssigende kokkenart (Staphylococeus pyogenes albus?). nicht aber solche unserer vroideu Bactcrien, heränwuchsen.

\section{Versuchsreihe.}

Als Ausgangsobject dienten unter den frïher buschriebenen Torsichtsmiasiregeln entnommene, hepatisirte und kïsig veründerte l'heile dox Lunge des Schwejn VJ, sowic Gewebssaft der Lunge und Milz and zwar wurden am 9. Norember:

1. ans dem Gewebssaft der Lunge nnd Jilz je drei Fleischpeptongelatinc-Platten angelegt, die jedoch kein positives Resultat lieferten,

2. mittelst eimes hepatisirten' Lungenstückchens Kaninchen $15 \mathrm{am}$ Rücken geimpft. Kaninchen 15 war an 12 . Norember todt. 
Sectionsbefund: Impfstelle eiterig infiltrirt und mit prall gefüllten Lymphsträngen versehen. Fmbolische Ferde in der Lober.

In den aus den embolischen Herden der Leber stammenden Ausstrichprïl)araten sehr zahlreich unsere ovoiden Bacterien:

Aus den Emboli der Iuber des Kaninchen 15 wurdon am 12. November geimpft:

1. Iraninchen 19 am Rücken,

2. Huh» 6 unter dem Flügel.

Kininchen 19 zeigte am folgenden Tage doppelschlïgiges Athmen und Frrenzlähmung; starb am 13. November.

Sectionsbefund wie bei Kaninchen 15 .

Ausstrichpräparate der Impfstelle und der Iiebcremboli zeigten schr Zahlireich unsere oroiden Bacterien.

Aus einem der Leberemboli des Kaninchen 19 wurden am 13. Nurember drei F'leischpeptongelatine-Platten angelegt, welche ain 20. Norember sämmtlich eine entsprechende Anzahl der früher beschriebenen charakteristischen Colonieen unserer ovoiden Bacterien zeigten.

line in der zwciten Verdünmmgsplatte gewachsene Colonio wurde am 20. November gelischt und damit ein Glüschen alkalischer Brühe inficirt, wolche bei Limmertemperatur sich am 22. November stark getrübt hatte. Yon dieser Brühe wurde am 22. Norember der dritte, berichungsweisc fünfte 'Theil einer. Praraz'schen Spritze roll dem

1. Impfschwein 1 in die rechte lunge gespritzt (mittelst Linstiches in einen der 'Lwischenrippenrïume),

2. dem Huhn 8 subcutan injicirt.

Impfischwein 1 war am 23. Formber todt, 10 stunden llikgh der Implimg.

Sectionsb efund: Fehlende Todtenstare, keine abnormen Hautfärbungen, um die Einstichstelle frische entzündliche Auflagerungen am scrösen Rippenund Lungenüber'zuge, blutiges Exsudat in der Brustiöhle und in Herzbeutel, rechte Lunge fast durchweg, die linke inselförmig grauroth hepatisirt. Mil\%schwellung, geringe Schwellung der braunrothen Leber; Yagenschleimhaut nur auf der Höhe der Falten geröthet, Dickdarm mit breiigem Inhalt grofüllt, nicht verändert.

In dem Hüssigen Exsudat der Brusthöhle, sowie in den entzündlichen Auflagerungen der Pleura unendlich viele unsercr oroiden Bacterien. weniger in den übrigen innereu Organen.

Huhn 8 war am 23. Norember traurig, frass nicht. tiel beim 1 แstossen um. In der Nacht rom 23. zum 24. Norember starb es.

Sectionsbefund: Starke eiterige Infiltration des Cnterhautbindegewobes an der Impfstelle. Greringe Leber- und Milzschwellung. 
Ausstrichpräparate der Impfstelle, des Blutes und der inneren Organe zeigen sehr zahlreich unsere ovoiden Bacterien.

Am 25. November. wurde aus der Milz des Huhn 8 geimplit: Kinninchen 27 am Ohre. J'od am 26. November.

Sectionsbefund ron den früheren nicht abweichend, nur fehlen die Lcberembolien. Ausstrichpräparate der Impfstelle und inneren Organe woisen unendlich zahlreich ovoide Bacterien auf.

Von dem Herzblut des Kaninchen 27 wurden am 26. November drei lileischpeptongelatine-Platten angelegt, in welchen unsere früher beschricbenen Colonieen in entsprechender Anzahl am 2. December gewachsen waren. In der Originalplatte fand sich ansserdem eine Colonie weisser Sircine, welche augenscheinlich das Wachsthum der oroiden Bacterien in jhrer Umgebung unterdrückt hatte.

łine vom Hermblut des Kaninchen 27 angelegte Stichoultur in l'leischpeptongelatine ging in charakteristischer Weise an.

Huhn 6 starb am 1. December.

S'cetionsbefund: Starke Abmagerung. Schwellung der mit zahlreichen embolischen Herden durchsetzten Leber.

Fine aus dem Herzblut angelegte stichenltur ging in der früher beschriebenen Weise an.

\section{Versuchsreihe.}

Als Ansgangsobject diente Herzblut des S'chwein VII, mit welchem kianinchen 14 am 9. November am rechten Ohre geimpte wurde. Tod am 13. November.

Scetionsbefund: Hämorrhagisch-citerige Infiltration der Impfistelle; leborembolien.

Drei am 13. November aus Her\%blut run Lrininchen 14 angelegte F'leischpeptongelatine-Platten entwickelten nach einigen l'agen charakteristische Colonieen.

Die Ausistrichpräparate verunglückten.

Kaninchen 18. mit einem Leberembolus des Kaninchen $14 \mathrm{am}$ 13. November geimplt, starb am 23. Norember.

Sectionsbefund: Abgemagerter Leichnam, eiterigc Infiltration der Impfstelle, Leberombolien.

Aus eincrn Leberembolus ron Kaninchen 18 wurde am 23. November Kaninchen $22 \mathrm{am}$ Ohr geimpft. Tod am 26. November.

Sectionsbefund wie früher, kcine Leberembolien, an der Impfstelle ein erbsengrosser Käseherd.

In den aus den inneren Organen angefertigten Ausstrichpräparaten fanden sich zahlreich unsere oroiden Bacterien. 
Mit diesen Schweinen war nummehr der ursprüngliche Senchenhestand aus dem bisher lediglich erwähnten Stall Nr. 1 erschöpft.

Ausserdem waren noch 60 Stück Schweine auf dem Senchengehöft iı fünf Ställen vorhanden, die folgendermassen vertheilt waren:

In zwei in dem Hauptstallgebäude neben dem inficirten Stall $\mathrm{Nr} .1$ gelegenen Kobenställen (Stall 2 u. 3) waren, und zwar in jo 6 Lioben, 16 bezw. 11 Schweine intergebracht.

In einem anderen, neben dem Garten gelegenen Kobenstalle (Nr. 4) waren in drei Koben neun Stüch eingestallt. Jenseits der Dorfstrasse endlich, etwa 30 Schritt vom Gehöt entfernt, waren in einem Holzschuppen und zwar in zwei gemeinschaftliche Krippen besitzenden stïllen (Nr.5 und 6) 24 Stück eingestallt.

lis stellte sich nachträglich heruus, dass in diesen beiden Ställen (Ni: 5 und 6) die anfangs erwähnten 23 inficirten Treiberschweine eine Zeit ling gestanden hatten, ehe sie in den Stall Nr. 1 gebracht wurden, und dass, nachdem letzteres geschehen, diese Ställe ron neuem mit 24 Sohweinen belegt wurden, obne dass eine Desinfection stattgefunden hïtte (s. den Situationsplan auf S. 419).

Alle diese Schweine gehïrten der vercdelten Isandrace an und standen in Siter von 2-9 Nonaten; nur zwei davon waren über $1 \frac{1}{2} \mathrm{Jahr}$ all.

Am 12. Norember wurde aus Stall 5 ein fünf Yonate altes schwoin (Nr. XIII) geschlachtet, welches bei der Oeffinung sich als gesund erwies.

Im 23. Norember rurde ein zweites 5-6 Monate altes Schwejn (Nr. XIV) alus Stall 4 geschlichtet, wolches zu Isebzeiten auf beiden Torderschenlieln contract war, $40.1^{\circ} \mathrm{C}$. T'emperatur und geringen Hustenreiz gezejgt hatte.

Sectionsbefund: Sehlcchte Ernährung, keine Hautverfärbungen, in der Iraut der Kniekchlen beider Vordersehenkel drci, bozw. zwei Hautgeschwüre mit zackigen, harten Rändern und speckigem Grunde; das darunter liegonde Bindegewebe ist verdickt, sulzig infiltrirt und von kleinen, prall gefüllten Jymphsträngen durchzogen.

Der untere Theil des Vorderlappens heider Lungen ist grauroth hepatisirt, die Bronchialdrüsen sind markig geschwollt; leichte Milzschwellung; Dickdarm gefüllt, nicht verändert.

Unsere ovoiden Baterien wurden nur in Ausstrichprïparaten des Milzsaftes und des Saftes des sulzig geschwellten Unterhautbindegewebes: nicht aher in denen nachgewiesen, welche aus dem Gewebssaft der hepatisirten Theile der Lungen und denjenigen der Bronchialdrüsen angefertiğt rurden. 


\section{Versuchsreihe:}

Am 23. November wurden aus dem Gewebssaft der hepatisirten Lungentheile des Schwein XIV

1. subcutan geimpft:

a) Kaninchen 23 am Rücken,

b) Huhn 9 unter dem Flügel;

2. drei Fleischpeptongelatine-Platten angelegt. Beide Thiere verblieben gesund, die Platten steril.

Situationsplan des Krzanowitzer Seuchengehöftes.

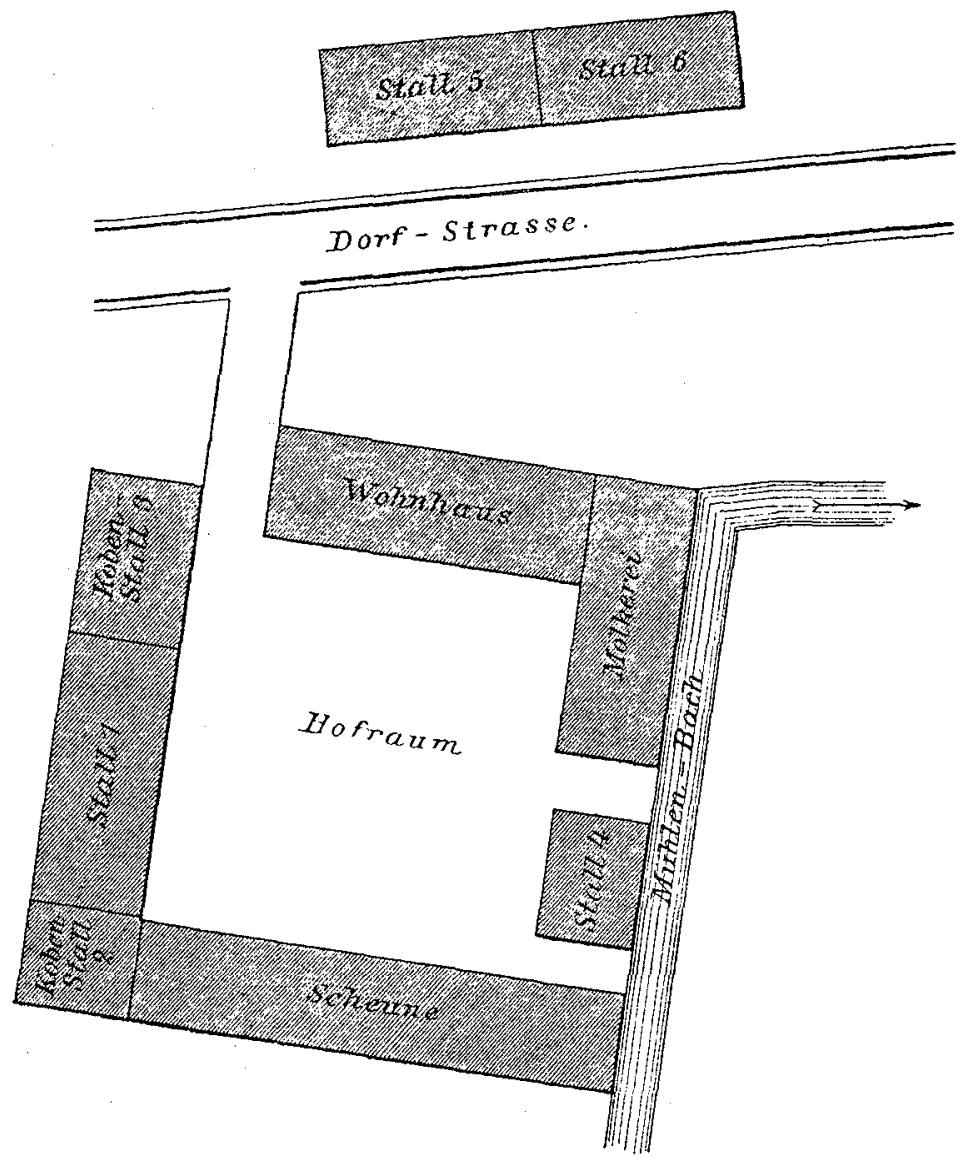

IX. Versuchsreihe.

Als Versuchsobject diente der unter den früher angegebenen Vorsichtsmassregeln der Milz des Schwein XIV entnommene Gewebssaft. 
Im 2t. Norember wurden damit

1. Kaniuchen 24 auf dem Rücken,

2. Huhn 10 unter einem Flügel geimpft,

3. Arci Hleischpeptongelatine-Platten angelegt.

Kaninchen $24 \mathrm{war}$ am 7. December todt. Sectiousbefund wie früher, nur fehlten die Leberembolien.

Im Gewebssaft der Impfistelle der imneren Organe und im Herzblut sehr zahlreich und ausschliesslich unsere oroiden Bicterien.

Aus dem Herzblut von Kaninchen 24 wurden

1. eine Gelatinestichcultur;

2. drei Gelatineplatten

angelegt, welche zu positivem Ergebnisse fübrten.

H uhn 10 war am 5. December todt. Sectionsbefund wie gewöhulich, ohne Leberembolien.

Ausstrichpräparate crgaben denselben Bufund wie bei lianinchen 2-1, auch in dem Ińnochenmarke waren unsere ovoiden Bacterien rorhanden.

Mit dem Tnhalte eines an der Impfstelle rorgefundenen, gefïllteu Lymphstranges des Huhn 10 wurde

Kaninchen 32 am Rüclien geimpft, welches am 10. December todt war.

Scetionsbefund: Bindegewebe an der Impfstelle eiterig infiltrirt, in ihrer Umgebung eiterige lymphangitis; Flankendrïsen bohnengross, mit. markiger Schnittfäche, Leber geschwellt und von zahlreichon Fmbolien durchsetzt. Im Herzbeutel röthliche Flüisigkeit. Geringe Milsschwellung. Darm geffïllt, nicht verändert.

In den ron der Impfstelle und der Flankendrüse angefertigten lusstrichpräparaten sehr zahlreich, in den ron Leher: und Jrilz angefertigten weniger zihlreich mnsere oroiden Bicterien.

Im 10. December wurdeu aus dem Herablat des Kaninchen 32 angelegt

1. drei Gelatineplatten,

2. eine Gelatinestichcult:ur

mit positivem Firgebnisse.

Die rom Getrebssaft der Milz des Schwein XIV am 24. Norember augelegten drei Golatineplatten waren am 3. December bis aluf die Originalplatte so sturk rerunreinigt, dass sie zu weiteren Versuchen nicht. benützt werden bonnteu.

In der rein erhaltencn Originalplatte dagegen fanden wir eine grosse 'Lahl allerdings nur mikroskopisch erkennbarer Colonieen von dem früher beschriebenen dussehen gewachsen. 
Da es wegen der grossen Anzahl und geringen Grösse der Colonieen nicht gelang, eine einzelne Colonie zu fischen, so wurde ein Theil der Gelatine im Brutkasten geschmolzen und am 3. December dem Kaninchen 29 unter die Haut der rechten Schulter gespritzt. Kaninchen 29 wir am 15. Decernber todt.

Sectionsbefund: Geringe Reaction an der Impfstelle. Wehrere embolische Herde in der Leber, trïhe Schwellung der Vieren.

In den aus der Impfstelle und dem Gewebssafte der inneren Orgaue angefertigten Ausstrichpräparaten sehr zahlreich unsere ovoiden Bacterien.

Am 29. November wurden drei neue, aus dem inficirten Gehüft stammende Schweine (Xr. XV, XYI und XVII) in Cosel geschlachtet, ron denen Nr. Xr und XYI, welche über 18. Mlonate alt waren, sich als: gesund erwiesen. Diesen folgten am 3. December ebendaher noch sieben durchweg erkrankte Schweine (Nr. XVIII bis XXIV).

Summarischer Sectionsbefund der Schweine XVII bis XXII. Koine Hautverfärbungen, kein Mautödem. Graurothe Hepatisation der unteren 'Theile der beiderseitigen Vorderlappen der Lungen, bei zwoi Stück ausserdem frische Pleuritis. Der Darmcanal durchweg normal und mit Fäces gefüllt.

Selır zahlrcich wurden unsere ovoiden Bacterien bei all' diesen erkrankten Schweinen in dem glasigen, zähen, graugelblichen Schleim gofunden, welcher die zu den hepatisirten Lungentheilen führenden Bronchialiiste erfüllte, ebenso in dem Gewebssaft der markig geschwellten Bronchialdrüsen, sehr wenig zahlreich, hin und wieder. gar nicht, fanden wir sies in dem aus den hepatisirten Lungentheilen stammenden Gewebssalte.

I)ie Schweine XXIII und XXIF waren am hochgradigsten erkrankt, weshallo besondere Sectionsberichte darüber aufgenommen sind:

Sectionsbefund von Schwein XXIII: Allogemeinbefund wic oben negativ. Im Uebrigen gramrothe insel- und folderartige Hepatisation der Vorderlappen, des rechten Iauptlappens und des äusseren Randes des linken Hauptlappens. Innerhalb der grauroth hepatisirten Felder fanden sich mehr gelbgefärbte, nicht lufthaltige Theile; hier und da an der Oberfäche frische Pleuritis. In den Bronchien an den hepatisirten Stellen glasiger, zäher, graugolber Schleim. Bronchialdrüsen markig geschwellt, schr gross.

Ausstrichprïparate ergaben die oroideu Bacterien in derselben Vertheilung, wie oben beschrieben.

\section{Yersuchsreihe.}

Als Ausgangsobject dienten die Inngen bezw. die Bronchialdrüsen ron Schwein XXII.

1. Am 4. Decumber wurde mit dem Gewebssafte einer hepatisirten Jungenstelle subcutan geimpft: Kaninchen Nr. 30. Am 10. December. war dasselbe todt. 
Sectionsbefund wie früher; an der Impfstelle fünf markstïckgrosse und $1 / 2$ cm starke sahnartige Infiltration des Unterhautbindegewebes, embolische Herde in der Leber, Milzschwellung.

Ausstrichpräparate zeigten unsere oroiden Bacterien in allen inneren Organen, auch in den embolischen lueberherden; an der Impfstelle besonders zahlreich.

Aus einem Leberherde wurden am 10. December drei Fleischpeptongelatine-Platten und eine Gelatine-Sticheultur angelegt. beides mit dem früher beschriebenen positiven Erfolge.

2. Aus dem Gewebssafte der Bronchialdrüsen wurden

a) Kaninchen 31 subcutan am Rücken geimpft,

b) drei Fleischpeptongelatine-Platten angelegt.

Kiminchen 31 war am 10. December todt. Sertionsbefund wis hei Kaninchen 30 .

In den Ausstrichpräparaten der Tmpfstelle und aller imneren Organe sehr zahlreich und ausschliesslich unsere ovoiden Bacterien.

In der aus dem Gewebssafte der Bronchialdrüse des Schwein XXIII am 4. Decemher angelegten Originalplatte fanden sich neben zahlreichen, rasch wachsenden, fremden Colonicen am 7. December einzelne noch sohr kleine Colonicen, die, wie Klatschprïparate zeigten, von unseren ovoiden Bacterien gebildet wurden. Di dis fischen einer einzelnen Colonie nicht. gelang, so wurde, um einem Verderben der Platte zuvor\%ukommen, ein Stïckchen Gelatine, in dem sich charalteristische Colonieen fanden, ansgehoben, bei Bruttemperatur geschmolzen und dem Fianinehen 34 inm 7. December miter dic Haut gespritzt.

Dasselbe war am 15. December todt. Sectionsbefund wic bei irininchen 30 und 31 ; eine Ichseldrïse stark geschwellt.

Ansstrichpräparate zeigen sehr zahlreich und ausschliesslich unser" oroiden Bacterien in der tehseldrüse, weniger zahlreich in den innerrn Organeu.

Sectionsbefund von Schwein XXIV: Koine Irautröthe, kein Hautödem. Darmcanal gefïlllt, nicht verändert. Lungen beide ziemlich alusgedehnt. mit härteren Knoten durchsetzt, Oberflä.che Heckig geröthet; Vorderlappen hepatisirt; zwisehen den Lungenläppchen dieser hepatisirten Stellen die Lymphgefüsse trüh-weiss. Am zweiten linken Iappen frische Pleuritis. Schnittfliche an den derberen Stellen grauroth, nicht lufthaltig, mit gelblichen peribronchitisehen Herden durchsetzt. Hauptbronchien mit blutigem, dis kleineren, zu den hepatisirten Strllen führenden mit glasigem, graugelben. zähem Schleim gefüllt. Die Bronchialdrïsen bilden ein Packet von $\&$ 'min Länge und sind markig geschwellt.

Crnstre oroiden Bacterien fanden sich am zahlreichsten in dem ghasign Bronchialschleim. 


\section{Versuchsreihe.}

Als Ausgangsobject dienten die Lungen und die Bronchialdrüsen von Schwein XXIV.

1. Aus dem Bronchialschleim wurden am 6. December drei Platten angelegt, welche nach einigen 'Tagen unsere charakteristischen Colonieen, neben zahlreichen anderen, gewachsen zeigten.

2. Mit dem Gewebssaft einer Bronchialdrüse wurde subcutan geimpft: Kaninchen 33 am 6. December.

Am 14. December tropft aus dem Impfcanal dieses Thieres sahnartiger Eiter, welcher, wie ein Ausstrichpräparat zeigt, vorwiegend neben fremden unsere ovoiden Bacterien enthält.

Mittelst dieses Eiters wurde subcutan geimpft: Kaninchen 38 am 14. December. Dasselbe starb am 25. December.

Sectionsbefund wie früher. Embolisehe Herde in der Leber. In allen Organen lediglich unsere ovoiden Bacterien.

Den gleichen Befund zeigte Kaninchen 33, welches am 16. December gestorben war.

3. Mittelst des Gewebssaftes eines hepatisirten Iungentheiles des Schwein XXIV wurden am 6. December:

a) ein Gläschen alkalischer Brühe,

b) drei Fleischpeptongelatine-Platten inficirt.

In der Originalplatte fanden sich am 12. December die charakteristischen Colonieen unserer ovoiden Bacterien vor.

In der alkalischen Brühe (1. sub a) war am 12. December unter Trübung derselben eine Reincultur unserer ovoiden Bacterien entstanden.

Drei Viertheile einer Pravaz'schen Spritze wurden davon dem Kaninchen 37 am 12. December von den Zwischenrippenräumen aus in die rechte Lunge gespritzt.

Kaninchen 37 war am 13. December todt.

Sectionsbefund: Leisten-, Hals- und Bugdrüsen markig geschwellt, die rechte Submaxillardrüse enthielt einen erbsengrossen Käseherd Brusthöhle mit röthlich-trübem Exsudat erfüllt. Rechte Lunge mit der Brustwand frisch verklebt, Lungen- und Rippenfell rechterseits uneben und mit frischen Gerinnseln bedeckt.

Graurothe Hepatisation der rechten Lunge. Trübe Schwellung der Nieren. Leber braunroth, mit zahlreichen embolischen. Herden durchsetzt. Milz geschwellt. Pulpa weich, Trabekel kaum erkennbar.

Sämmtliche Organe enthielten lediglich unsere ovoiden Bacterien in unendlicher Zahl, besonders in dem pleuritischen Exsudate. 
a) Mit dem Lebersaft des Kaninchen 37 wurde am 13. December Kaninchen 47 geimpft.

Dasselbe starb am 9. Januar 1889 und zeigte makroskopisch und mikroskopisch den charakteristischen Befund.

b) Aus dem Herzblut des Kaninchen 37 wurden am 13. December drei Fleischpeptongelatine-Platten angelegt.

Am 18. December zeigten alle drei Platten die Colonieen der ovoiden Bacterien gewachsen.

Ein aus der Originalplatte entnommenes, mit den Colonieen durchsetztes Gelatinestückchen wurde bei Brutwärme geschmolzen und dem Kaninchen 39 am 18. December unter die Hant gespritzt. Tod am 28. December.

Sectionsbefund nach jeder Richtung hin negatir.

Die Krankheit griff im Anfang December auch auf die übrigen Ställe über. Wir sahen nunmehr bezüglich des uns weiterhin zugehenden MLaterials von weiteren Impfversuchen ab.

Zunïchst wurden am 8. December sechs nene, ans Stall 2 stammende Schweine (Nr. XXV bis XXX) geschlachtet, welche sümmtlich sich als krank erwiesen.

Sectionsbefund der Schweine XXV bis XXIX: Keine Hautverfärbungen, kein Hautödem, keine Veränderungen am Darmcanal; die Vorderlappen der Lungen in grösserer oder geringerer Ausdehnung grauroth hepatisirt. Die zu den hepatisirten Theilen führenden Bronchien mit zähem, graugelbem, glasigem Schleim erfüllt; Bronchialdrüsen markig geschwellt.

Ausstrichpräparate des Gewebssaftes der Inngen und des Bronchialschleimes zeigten im Ganzen wenig zahlreich ovoide Bacterien; in zwei Präparaten wurden einzelne Haufen derselben vorgefunden; jedenfalls waren sie im glasigen Bronchialschleim zahlreicher vertreten, als im Gewebssafte der Iungen.

Sectionsbefund des Schwein XXX: Keine Hautverfärbungen, kein Hautödem, keine Veränderungen am Darm. Lungen unvollständig zusammengefallen, die linke felderweise, die rechte total grauroth hepatisirt, theilweise verwachsen und mit theils frischerem, pleuritischem Belage, theils mit gallertartiger Schwarte bedeckt. Die hepatisirten Stellen zeigen anf der Schnittfläche zahlreiche, mehr graugelb gefärbte, käsige Stellen. Bronchialdrüsen markig geschwellt.

Ausstrichpräparate zeigen im Gewebssaft der hepatisirten Iungentheile und der Bronchialdrüsen, besonders aber im Bronchialschleim zahlreich unsere ovoiden Bacterien. 
Der Restbestand von 17 Schweinen der Ställe 5 und 6 wurde nebst sechs anderen, aus den anderen Ställen. stammenden Anfarrg December nun in den evacuirten und desinficirten Stall 1 gebracht und Stall 5 und 6 nach gründlicher Desinfection mit 20 neu angekauften Schweinen besetzt.

Die nunmehr in Stall 1 befindlichen 23 Schweine zeigten am 15. December starke Zunahme des Hustens. Die Anfälle traten besonders beim Oeffnen der Fenster oder der Thür ein.

Das Athmen war nicht auffällig verändert, ebenso wenig die Fresslust, dagegen erfolgte auch später keine Besserung des Futterzustandes, trotz des vorzüglichen Futters. Drei dieser Schweine zeigten eine Temperatur von 38.6 resp. 39.2 bezw. $39 \cdot 9^{\circ}$.

Am 18. December wurden wiederum ein aus Stall 2 stammendes Schwein (Nr. XXXI), welches zu Lebzeiten keine Krankheitserscheinungen gezeigt hatte, und am 3 . Januar 1889 wiederum fünf neue, aus Stall 3 und 4 stammende Schweine (Nr. XXXII bis XXXVI) geschlachtet, welche sämmtlich den gleichen Sectionsbefund darboten, wie XXV bis XXX, eines mehr, das andere weniger; in den älteren, härteren, hepatisirten Stellen der Lungen fanden sich bis erbsengrosse, gelbe, nekrotische Herde.

Nach den Ausstrichpräparaten zu urtheilen, enthielten die frischen pleuritischen Beläge zahlreiche, der glasige Bronchialschleim sehr zahlreiche, zu Haufen gelagerte, der Gewebssaft der grauroth und frisch hepatisirten Lungentheile dagegen nur wenige unserer ovoiden Bacterien.

. Aus dem glasigen Bronchialschleim einer dieser Lungen wurden am 3. Januar 1889 drei Fleischpeptongelatine-Platten angelegt.

Nach einigen Tagen erwies sich die Originalplatte verschimmelt, in der ersten Verdünnungsplatte dagegen waren einige, mit ringfiirmiger /Jeichnung versehene Colonieen gewachsen, welche ans Reinculturen unserer ovoiden Bacterien bestanden.

Am 11. Januar 1889 gelangten wiederum sechs aus Stall 1 stammende Schweine (Nัr. XXXVIr bis XLII) zur Abschlachtung.

Alle zeigten den obigen Befund; im Grossen und Ganzen waren die Lungenveränderungen hochgradiger und weiter fortgeschritten, als wir es bisher gesehen hatten. In sämmtlichen, vom glasigen Bronchialschleim und dem Gewebssaft, sowie von den käsigen Stellen der Lungen angefertigten Ausstrichpräparaten fanden wir unsere ovoiden Bacterien, am zahlreichsten immer in dem zähen, graugelben Bronchialschleim. In dem Darmcanale fand sich nichts Abnormes.

Besonders hochgradig waren Schwein XXXVII und XXXVIII erkrankt. 
Die Lunge des ersteren, welches zu Lebzeiten 39.9 'Temperatur gehabt, wurde alsbald an das pathologische Institut der Thierärztlichen Hochschule zu Berlin geschickt. Herr Professor Schütz theilte uns in liebenswürdiger Weise die Ergebnisse seiner Untersuchungen, durch welche er Schweineseuche feststellte, mit.

Sectionsbefund des Schwein XXXVIII: Keine Hautröthe, kein Hautödem, keine Veränderungen im Dickdarm.

Alte diffuse und frische Pleuritis, frische Pericarditis. Lungen sehr gross, namentlich die rechte. Feste, dunkelbraunrothe Hepatisation, besonders der Vorderlappen, inselformige graurothe Hepatisation der Hinterlappen. Mittlerer rechter Lappen hart, Schnittfläche höckerig, grauroth mit einem Stich in's Gelbliche, ähnlich der eines Markschwammes. In das hepatisirte Gewebe kleine, käsige, gelb gefärbte Herde eingesprengt. Luftröhrenschleimhaut geschwellt; die kleineren und mittleren, innerhalb der erkrankten Stellen liegenden Luftröhrenäste durch graugelben, zähen, glasigen Schleim verstopft, der bei Druck auf die Schnittfläche in Pfropfen hervortritt und beim Nachlassen des Druckes sich in die Luftröhrenäste wieder zurückzieht. Bronchialdrüsen sehr gross mit markiger, stellenweise käsig durchsetzter Schnittfläche.

Alte und frische Perihepatitis, keine Schwellung der auf dem Durchschnitt trockenen Milz. Mesenterialdrüsen leicht geschwellt, ihr Durchschnitt feucht, blassgrau.

Ausstrichpräparate zeigten unendlich zahlreiche Exemplare unserer ovoiden Bacterien, meist haufenweise liegend, in dem glasigen Bronchialschleim, zahlreich in den Mesenterialdrüsen und den frischen Entzündungsproducten der serösen Häute, besonders des Leberüberzuges, wenige dagegen in dem entzündeten Lungengewebe und in den käsigen Herden, sowie in der Leber. In den von dem Gewebssaft der Milz und der Bronchialdrüsen angefertigten Ausstrichprüparaten konnten wir dagegen keine Bacterien nachweisen.

\section{Versuch.}

Aus dem glasigen Bronchialschleim des Schwein XXXVII wurden am 11. Januar

1. drei Fleischpeptong elatine-Platten angelegt, in welchen wir am 17. Januar unter anderen zahlreiche Colonieen unserer ovoiden Bacterien nachweisen konnten;

2. drei Reagensgläschen mit alkalischer Brühe inficirt. Bis auf eines trïbte sich der Inhalt in den Gläschen während der nächsten Tage bei Zimmertemperatur, and am 19. Januar fanden wir in den rou der getrübten Brühe angefertigten Ausstrichpräparaten neben anderen sehr zahlreich unsere ovoiden Bacterien'vertreten. 
Am 14. Januar d. J. gelangten vier neue, aus Stall 1 stammènde Schweine (Nr. XLIII bis XLVI) zur Abschlachtung, die bei Lebzeiten viel gehustet hatten, in ihrem Ernährungszustande heruntergekommen waren und Temperaturen von 39.5 bis 40.6 gezeigt hatten.

Nit Ausnahme des Schweines XLIII, welches intensivere und ausgedehntere Erkrankungen seiner Lungen zeigte, erwiesen sich bei allen diesen Thieren nur die Vorderlappen und auch diese nur streifenförmig grauroth hepatisirt. Milzschwellung, Hautverfärbung, Hautödem oder Veränderungen im Darmcanal waren bei keinem der Schweine vorhanden.

Ausstrichpräparate des glasigen Bronchialschleimes wiesen zahlreiche, theils kettenförmig, theils flechtwerkartig angeordnete, oft in Häufchen gelagerte, aber auch vereinzelte Exemplare unserer ovoiden Bacterien. Ausstrichpräparate des Gewebssaftes der hepatisirten Lungentheile keine, oder nur vereinzelte Exemplare derselben auf.

\section{Versuch.}

Drei aus dem glasigen Bronchialschleim der Iunge des Schwein XIII am 14. Januar angelegte Fleischpeptongelatine-Platten wiesen nach einigen Tagen die Colonieen unserer ovoiden Bacterien in entsprechender Anzahl auf.

Die gleiche geringgradige Erkrankung zeigten zwei von uns, nachdem sie in dem inficirten Gehöft erkrankt und zu wissenschaftlichen Zweeken seitens des Besitzers uns überwiesen waren, in besonderem Verwahrsim zu Cosel gehaltene Schweine Nr. XLVII und XLVIII, welche am 21. Januir resp. 11. Februar geschlachtet wurden.

Ausserdem war zu gleicher Zeit ein drittes Schwein Nr. IT von uns, nachdem es bereits erkrankt war, nach Cosel übergeführt wordeu.

Schwein $\Pi$ wurde am 20. Februar 1889 geschlachtet, nachdem es bei Lebzeiten 14 Tage vorher $40 \cdot 8^{\circ}$ Temperatur und in der ganzen Teit Husten und Athembeschwerden gezeigt hatte.

Sectionsbefund: Ungefähr vier Monate alter Borg. Starke Abmagerung, keine Hautverfärbungen, kein Hautödem. Lungen unvollständig zusammengefallen, an der Oberfläche beiderseits stellenweise mit frischem pleuritischem Belage bedeckt. Beide Vorder- und Mittellappen, sowie der vordere Theil der Hinterlappen derb, nicht lufthaltig; in dem hinteren Theil beider Hinterlappen bis haselnussgrosse, derbe Knoten. Schnittfläche der Lungen an den hepatisirten Stellen im Allgemeinen höckerig," gelbroth mit dazwischen liegenden grauroth hepatisirten Inseln, deren Schnittfäche glatt erscheint. Innerhalb der gelbrothen Stellen einzelne gelbe, z. Th. verkalkte Herde. In der Luftröhre und den grossen Bronchialästen feinblasiger, rother Schaum, in . den feinsten Bronchien nur hier und da glasiger, graugelber, sehr zäher Schleim. Bronchialdrüsen markig geschwellt, von käsigen Herden durch- 
setzi und mit der Umgebung verwachsen. Am Herzbeutel und Herzen nichts Abnormes. Milz wenig geschwellt. Leber und Nieren normal. Darmschlingen unter einander und mit der Bauchwand durch alte feste Stränge verwachsen. Magen-, Dünn- und Dickdarm-Schleimhaut auch an der Meocoecal-Klappe nicht verändert, ebenso wenig die Mesenterialdrüsen. Im ganzen Darmcanal normaler Futterbrei. Blasenschleimhaut normal. Bauchfell überall glatt, loch verdickt und grauweiss. Zwischen Damm und Castrationsstelle eine taubeneigrosse mit Käseherden durchsetzte Lymphdrüse. An der Castrationsstelle zwei, von fibröser Kapsel umgebene, wallnussgrosse, kugelige Cysten, erfüllt mit käsig-eiterigem grüngelben Inhalt. Am unteren Theil der Vorderwand der Blase, dieser extraperitoneal zu beiden Seiten der Mittellinie aufsitzend, rechts zwei, links eine Cyste von derselben Gestalt und demselben Inhalt wie oben beschrieben. Eine weitere Anzahl von sieben solchen Cysten findet sich genau in der Mittellinie, der vorderen Bauchwand subperitoneal aufsitzend, bis zum Nabel herauf rosenkranzartig aneinander gereiht, unter cinander und mit einzelnen Darmschlingen durch feste fibröse Stränge verwachsen. Eine weitere solche Cyste sitzt endlich ebenfalls subperitoneal an der seitlichen Bauchwand, dem linken Rippenbogen entsprechend, 3 cm nach aussen von der nächsten der vorher beschriebenen Cysten.

Inguinal-Drüsen geschwellt, auf dem Durchschnitt von Käseherden durchsetzt.

In den Ausstrichpräparaten fanden sich unsere ovoiden Bacterien in folgender Vertheilung:

a) in den käsigen Massen der Cysten anscheinend als Reincultur,

b) im Bronchialschleim zahlreich,

c) in den verkästen Iungentheilen ziemlich zahlreich,

d) in den verkästen Theilen der Bronchialdrüsen spïrlich,

e) in der Milz ganz vereinzelt,

f) in den grauroth hepatisirten Tungenpartieen wuden sie nicht rorgefunden.

\section{Versuchsreihe.}

Von Schwein IT, wurden am 20. Februar 1889

a) aus dem Bronchialschleim:

1. drei Fleischpeptongelatine - Platten angelegt, in welchen $\mathrm{am}$ 24. Februar charakteristische Colonieen zu bemerken waren.

Aus dieser Platte wurden mehrere Colonieen gefischt und mit je einer derselben drei Gelatine- and zwei Agarstichculturen angelegt, wolche nach einigen Tagen charakteristisches Wachsthum zeigten.

2. Eine Brühecultur inficirt, welche am 24. Februar bei Zimmertemperatur getrübt war und die oroiden Bacterien in Reincultur enthielt.

Da der Besitzer den Stall 1 mit 14 Kälbern besetzt hatte und unter diesen nach seiner verspäteten Mittheilung einige angeblich an Aufblähung. gestorben waren, suchten wir festzustellen, ob die Krankheit auf Kälber 
übertragbar sei, und impften am 26. Februar 1889. mit der obigen Brühecultur (s. unter 2), deren pathogene Wirksamkeit durch den Tod eines damit geimpften Kaninchens 67 erprobt worden war, Impfkalb 1 und 2, ersteres subcutian mit einer ganzen, Nr. 2 in die rechte Lunge vom Intercostalraum aus mit einer halben Spritze voll.

Beide Kälber waren vier Wochen alt, vorher frei von Krankheitserscheinungen, zeigten eine Mastdarmtemperatur von $39.7^{\circ}$ und wurden in Stall 3 untergebracht.

Impfkalb 1 war sechs Stunden nach der Impfung todt.

Sectionsbefund: Der ganze Cadaver durch Hautemphysem paukenartign aufgetrieben. Unterhautbindegewebe des ganzen Leibes stark ödematös geschwellt, besonders in der Umgebung der Impfstelle, wo zahlreiche kleine Hämorrhagien gefunden wurden. Die der Impfstelle nächstliegenden Lymphdrüsen geschwellt, mit hämorrhagischen Herden durchsetzt. Brusteingeweide normal, Baucheingeweide stark von Gas aufgetrieben, Milz mässig geschwellt, Pulpa schmutzig grauroth, schmierig, Leber geschwellt, an der Oberfläche bis ein Zoll tief milcheaffeefarbig, Consisten\% schlaff, Gewebe brüchig; auf dem graurothen Durchschnitt die Zeichnung nicht erkennbar. Nieren trüb geschwellt. Schleimhaut und Drüsen des Darmcanales nicht vẹrändert, bis auf einzelne stärker geröthete Stellen der Dünndarmschleimhaut.

In den Ausstrichpräparaten fanden sich ausschliesslich unsere ovoiden Bacterien in folgender Vertheilung:

1. an der Impfstelle und in der Leber ausserordentlich zahlreich,

2. im Blut in einzelnen Häufchen,

3. in der Milz nicht auffindbar.

Aus Leber, Blut und Milz wurden je zwei FleischpeptougelatinePlatten am 27. Februar angelegt, in welchen sämmtlich die Colonieen unserer ovoiden Bacterien wuchsen, nur die Milzplatten blieben steril. Die Verimpfung einer aus einer dieser Colonieen stammenden Brühecultur auf das Kaninchen 68 hatte positiven Erfolg, indem das Kaninchen nach kurzer Zeit starb und einen charakteristischen Befund aufwies.

Impfkalb 2 zeigte nach dem Berichte des Eigenthümers durch mehrere Tage schlechte Fresslust und Fieber. Am 3. März fanden wir keine Krankheitserscheinungen an ihm mit Ausnahme von geringgradigem Hieber.

Ferner wurden von Schwein IL am 20. Februar angelegt:

b) aus Herzblut und Gewebssaft der Milz je zwei Platten und je ein Gelatinestich, die aber alle steril blieben,

c) aus dem Cystenkäse drei Fleischgelatine-Platten.

In diesen Platten wuchsen lediglich Colonieen einer in Ausstrichpräparaten unseren ovoiden Bacterien selır äbnlichen, nur etwas plumperen 
Bacterienart, die indess ein durchaus von dem der unserigen abweichendes Wachsthum, sowohl in der Platte, wie im Stich zeigten; auch fehlte die Ringbildung an den Colonieen.

Impfversuche mit dieser Bacterienart hatten ein negatives Resultat.

Am 30. Januar wurden zu Krzanowitz wiederum drei neue Schweine (Nr. I bis III) geschlachtet. Nr. I und II reigten (bei Abwesenheit sonstiger Veränderungen an der Haut, dem Unterhautzellgewebe und Darmeanal) nur theilweise graurothe Hepatisation der Vorderlappen, Nr. LII ausserdem frische Pleuritis und gelbe nekrotische Herde in den hepatisirten Lungentheilen. Bei allen waren die Bronchialdrïsen markig goschwellt, besonders bei Schwein LII.

Die mikroskopische Untersuchung der Ausstrichpräparate zeigte durchweg auffallend wenige unserer ovoiden Bacterien, selbst in den pleuritischen Hutzündungsproducten und im Bronchialschleim, noch weniger aber im Gowebssaft der grau hepatisirten Lungentheile und in den verkästen Stellou.

\section{Versuch.}

Aus den verkïsten Lungentheilen des Schwein liI wurden am 30. Januar drei Fleischpeptongelatine-Platten angelegt, welche wiederum nach einigen Tagen die charakteristischen Colonieen unserer ovoiden Bacterien zeigten.

Wir bemerken woch, dass wir in allen Fällen, in denen es zur Verkäsung gekommen war, die verkästen Stellen auf Tuberkelbacillen durch Färbung der Ausstrichpräparate mittelst Ziehl'scher Lösung untersuchten, in keinem aber Tuberkelbacillen nachzuweisen im Stande waren.

Die von uns beobachteten pathologischen Befunde lassen keinen Zweifel darüber, dass wir es in allen Fällen, mit Ausnahme der überhaupt gesund gebliebenen Schweine, mit ein und derselben Krankheit zu thun hatten, da sie alle in dem Vorhandensein einer zunächst katarrhalischen, später zur Verkäsung und Nekrose führenden Erkrankung der Lungen übereinstimmten.

Die Krankheit ist in den vorher durchaus gesunden Bestand durch die im August 1888 angekauften Treiberschweine offenbar eingeschleppt worden.

Diese Treiberschweine waren zunächst in den Ställen 5 und 6 untergebracht und nach längerem Aufenthalte daselbst nach Stall 1 übergeführt worden. 
Stall 5 and 6 wurden hierauf mit 20 anderen Schweinen belegt.

Die ersten Krankheitsfälle zeigten sich unter diesen Treiberschweinen nach geschehener Ueberführung im Anfang September. Von ihnen ging die Krankheit zunächst auf sieben andere, dem ursprünglichen Bestande angehörige, aber ebenfalls in Stall 1 befindliche Schweine über.

Vom November ab trat die Krankheit auch in den übrigen Ställen auf.

Selbst die in den isolirt jenseits der Dorfstrasse gelegenen Ställen 5 und 6, nach Evacuirung der Treiberschweine untergebrachten 20 Thiere, welche mit den Treibersehweinen gar nicht in directe Berührung gekommen waren, blieben im November nicht verschont.

Auch eime mit gründlicher Desinfection verbundene abermalige Lvacuirung der Ställe 5 und 6 blieb ohne Erfolg, denn es zeigte sich trotz dieser Massregeln die Krankheit unter den im December abermals erneuten, einem fremden, durchaus unverdächtigen Stalle entstammenden Insasseı dieser Stäle 5 und 6 zum zweiten Male, und zwar im Februar 1889.

Im Ganzen erkrankten von dem 63 Stück betragenden Bestande 60 'Thiere.

Von diesen wurden, abgesehen von den zwei Stück, deren Lungen nur uns übermittelt wurden, 52 von uns untersucht.

Von den drei gesund gebliebenen waren zwei über $1^{1 / 2} \mathrm{Jahr}$, von den erkrankten keines über 1 Jahr alt.

Sämmtliche Schweine gehörten der veredelten Landrace an.

In allen Fällen war der Verlauf ein sehr chronischer und konuten wir nie den von Heuschel in Puttlitz und den ron Grafunder in Landsberg geschilderten acuten Verlauf beobachten.

Die während des Lebens beobachteten Krankheitserscheinungen bestanden in Husten, der sich besonders bei Zutritt frischer Luft in den Stall steigerte, Athembeschwerden, später in Störung der Fresslust, verbunden mit Abmagerung: Die Körpertemperatur schwankte zwischen 39 bis $40 \cdot 6^{\circ}$.

Der Sectionsbefund ergab im Allgemeinen an Haut- und Unterhautzellgewebe keine Veränderungen. In den meisten Fällen, welche, da die Abschlachtung naturgemäss möglichst frühzeitig nach dem ersten Auftreten der oben geschilderten Krankheitssymptome vorgenommen wurde, die Krankheit in ihrem Anfangsstadium zeigten, beschränkten sich die krankhaften Veränderungen auf graurothe Hepatisation der unteren Theile der Vorderlappen der Lungen und markige Schwellung der Bronchialdrüsen. Bei weitergehender Erkrankung waren auch die Mittel- und Hinterlappen in Mitleidenschaft gezogen, letztere indess meist nur an 
kleinen, isolirten Stellen. Immer bildete der Bronchus den Mittelpunkt der hepatisirten Stellen. Da, wo die Krankheit in- und extensiv weiter fortgeschritten war, erschien das hepatisirte Gewebe auf dem Durchschnitt trockener und von mehr gelbrother Farbe, die Schnittfläche höckerig. In noch späteren Stadien gesellte sich theilweise Verkäsung der hepatisirten Stellen und der Bronchialdrüsen dazu. Nie waren indess in den kïsig. veränderten Theilen Tuberkelbacillen nachzuweisen. Betheiligung des pleuralen Ueberzuges der Iungen wurde nur in den hochgradigeren, Betheiligung des Pericards nur in mehreren sehr hochgradigen Fällen beobachtet. Peritonitis, und zwar frische, wurde nur einmal gefunden. An den übrigen Organen, besonders in der Haut, am Unterhautzellgewebe, Leber, Nieren, Blase und dem Magendarmcanal wurden keine Veränderungen wahrgenommen. Ebenso war die Milz nur selten und auch dann nur geringgradig geschwellt.

Ein Schwein (Nr. IL) zeigte neben den Resten überstandener Banchfellentzündung eine Anzahl subperitoneal an der Blase und der vorderen Bauchwand gelegener, mit käsigem Eiter gefüllter Cysten, neben ebensolchen an der Castrationsstelle; ein anderes (Nr. VI) harte, wulstige Hautgeschwüre am rechten Hinterschenkel mit Schwellung und Verkäsung der Leistendrüsen und einem jauchigen Hautabscess an der inneren Schenkelfäche; ein drittes (Nr. XIV) ähnliche Hautgeschwüre an den Vorderschenkeln. Aber auch bei diesen drei Schweinen waren die Tungen in der beschriebenen Weise erkrankt.

Diese 'Thatsachen erweisen, dass wir es mit einer äusserst ansteckenden, chronisch verlaufenden Lungenentzündung der Schweine zu thun hatten, die auch ohne directe Berührung eines kranken mit einem gesunden Thier auf letzteres übertragen werden kann, und deren Erreger in fast allen Fällen seinen Fingang in den Körper auf dem Wege der Respirationsorgane gefunden haben musste, von deren Erreger es ferner wahrscheinlich war, dass er ausserdem in zwei Fällen auch von der verletzten Oberhaut aus in den Körper eingedrungen war. In allen Fällen gingen die krankhaften Veränderungen nicht erheblich über die Invasionsstelle hinaus. Die Krankheit bewahrte fast immer den localen Charakter, namentlich fehlten durchweg irgend welche erhebliche Veränderungen an der Milz und dem Darm, wie sie den septicämischen Krrankheiten eigenthïmlich sind.

Bis vor wenigen Jahren noch herrschte auf diesem Gebiete viel Unklarheit. 
Den Arbeiten von Löffler ${ }^{1}$ und besonders von Schütz ${ }^{23}$, ferner von Lydtin und Schottelius ${ }^{5}$ und Salmon ${ }^{6}{ }^{7}$ verdanken wir die Kenntniss dreier Seuchen der Schweine und zwar:

1. des Schweinerothlaufs,

2. der Schweineseuche,

3. der Schweinepest.

Die Unterschiedsmerkmale dieser drei Krankheiten hat Schütz ${ }^{8}$ folgendermassen gekennzeichnet:

„1. Rothlauf (Stäbchenrothlauf) ist eine Krankheit, bei der nur allgemeine Infectionserscheinungen, wie beim Milzbrand, bei der Septicämie u. s. w. wahrgenommen werden.

Die wichtigsten anatomischen Merkmale sind:

Milatumor, blutige Magendarmentzündung, blutige Nierenentzündung, parenchymatöse Entzündung der Leber, des Herzens, der Muskeln, Röthung der Haut und geringe Ansammlung von Flüssigkeit in den Körperhöhlen.

2. Schweineseuche ist eine Lungenbrustfellentzündung, die mit Absterben von Lungentheilen und leichten Infectionserscheinungen verbunden ist: keine oder geringe Schwellung der Milz, leichte Trübung der grossen Parenchyme und Magendarmkatarrh. Nimmt die Krankheit einen chronischen Verlauf, so entstehen käsige Zustände der Lungen, die sich nach Art der Tuberculose ausbreiten und ähnliche Zustände in den Lymphdrüsen, Gelenken u. s. w. hervorrufen können.

Käsige Veränderungen an der Schleimhaut des Magens und Darms sind bis jetzt nicht beobachtet worden.

- Experimentelle Untersuchungen über den Schweinerothlauf. Arbeiten aus dem Kaiserl. Gesundheitsamt. Beihefte z. d. Veröffentlichungen d. Kais. Gesundheitsamtes. Berlin 1885. Bd. I. Hft. 1 u. 2. S. 46.

${ }^{2}$ Ueber den Rothlauf der Schweine und die Impfung mit demselben. Ebenda. Berlin 1885. Bd. I. Hft. 1 u. 2. S. 56. - Archiv für wissenschaftl. und praktische Thierheilkunde, 1885. Bd. XI.

s Ueber die Schweineseuche. Arbeiten aus dem Kaiserl. Gesundheitsamte. 1886. Bd. I. S. 376. - Archiv für wissenschaftl. u. prakt. Thierheilkunde. 1886. Bd. XII.

${ }^{4}$ Schütz, Die Schweinepest in Dänemark.

5 Der Rothlauf der Schweine, seine Entstehung und Verhütung (Schutzimpfung nach Pasteur). Nach amtlichen Ermittelungen im Grossherzogthum Baden im Auftrag des Grossherzogl. Ministeriums der inneren Angelegenheiten. Wiesbaden 1885. Bergmann.

${ }^{6}$ On swine plague. Second annual report of the bureau of animal industry for the year 1885. Washington 1886.

7 Investigations of swine disease (Hog Cholera and infections pneumonia in swine [swine plague]). Report of the Commissioner of Agriculture for the year 1886 . Washington 1887. p. 603 .

8 A. a. 0 . 
3. Schweinepest ist eine Krankheit des Verdauungsapparates, bei der vornehmlich der Dickdarm erkrankt ist.

Letzterer ist in der Regel der Sitz einer tiefen Diphtherie. Gleichzeitig leiden die nachbarlichen Lymphdrüsen und sind die Erscheinungen einer leichten allgemeinen Infection nachzuweisen. Die Krankheit ist oft mit Reizungsprocessen in den Lungen vergesellschaftet. “

Wenn eine dieser drei infectiösen Schweinekrankheiten vorlag, so konnte dies weder der uns von früheren, eingehenden Untersuchungen sehr wohlbekannte Schweinerothlauf sein, demn es fehlten die diesem eigenthümlichen Hautverfärbungen, ferner die ihm eigenthümliche septicämische, erhebliche Schwellung der Milz, die Veränderungen am Darm und seinen Drüsen, an Leber und Nieren, noch konnte es sich um Schweinepest handeln, da diphtheritische Veränderungen am Darm nie gefunden wurden.

Dagegen stimmte unser Krankheitsbild mit dem von Schütz ${ }^{1}$ als der Schweineseuche angehörig geschilderten derart überein, dass wir von vornherein wenig Zweifel mehr über die Indentität beider Krankheiten hegen konnten.

Schütz ${ }^{1}$ beschreibt ja die Schweineseuche als eine infectiöse, nehrotisirende Pneumonie.

Jeden Zweifels darüber enthoben uns die Ergebnisse unserer auf die Isolirung des Infectionsträgers gerichteten Versuche und die mit demselben angestellten Infectionsversuche.

Vermittelst directer subcutaner Verimpfung von Material, welches aus den Organen der erkrankten Schweine stammte, gelang es uns bis auf zwei Fälle, durchweg bei Kaninchen beziehungsweise Hühnern eine für die Impflinge tödtliche Krankheit zu erzeugen.

Benutzt wurden dazu:

die krankhaften Lungen . . . . . 8 mal,

Bronchialschleim . . . . . . . . . 3 mal,

die Bronchialdrüsèn . . . . . . . . 2 mal,

das Herzblut . . . .. . . . . . 1 mal,

die $\mathrm{Milz}$. . . . . . . . . . . $2 \mathrm{mal}$,

die Leistendrüsen . . . . . . 1 mal.

Diese Impfkrankheit verlief insofern unter einem von dem an den Schweinen beobachteten Krankheitsverlaufe abweichenden Bilde, als sie unter den Erscheinungen einer meist acuten Septicämie zum Tode führte.

Gewöhnlich wurden die Thiere einige Stunden nach der Impfung traurig, athmeten schwer unter schnell steigender Temperatur und Schwellung der Impfstelle; später folgten (bei Kaninchen) deutliche Kreuz-

1 A. a. 0. 
schwäche, hin .und wieder Durchfälle. Unter zunehmender Somnolenz trat der Tod ein in einem Falle schon nach 24 Stunden, in anderen am 2. bis 13. Tage.

Der makroskopische Leichenbefund bestand in mehr oder. weniger anśgedehnter eiteriger Infiltration des subcutanen Bindegewebes der Impfstelle, verbunden mit eiteriger Lymphangitis daselbst.

Die Schnittfläche der nur in zwei Fällen hepatisirten, in den übrigen durchans lufthaltigen Lungen war hin und wieder rothfleckig; Milz und Leber waren meist, allerdings nicht hochgradig trübe geschwellt, letztere enthielt in zahlreichen Fällen embolische Herde.

Die mikroskopische Untersuchung des der Impfstelle entnommenen Eiters wies immer einen sehr reichen, die Untersuchung des Blutes und des Gewebssaftes der inneren Organe einen mit der Krankheitsdauer im Allgemeinen im umgekehrten Verhältniss stehenden Gehalt an einer von den Rothlaufstïbchen in Form und Wachsthum durchaus verschiedenen -Bacterienart auf, deren constantes und ausschliessliches Vorhandensein darauf hindentete, dass diese Bacterien mit der Entstehung der Impfkrankheit in ursüchlichem Zusammenhange standen, um so mehr, als es gelang, durch weitere Verimpfung der Organtheile der an der Krankheit gestorbenen Thiere fast durchweg und immer wieder dieselben Krankheitserscheinungen und denselben makroskopischen, wie mikroskopischen Befund hervorzurufen.

An Impfkalb 1 fiel die durch Züchtung and mikroskopische Untersuchung festgestellte absolute Abwesenheit dieser Bacterien in der augenscheinlich frisch gesehwellten Milz gegenüber dem Reichthum an denselben im Blute und namentlich in der Leber auf.

Der endgültige Beweis dafür, dass wir in dieser Bacterie den Erreger dieser für Kaninchen, Hühner und Kälber tüdtlichen Impfkrankheit vor. uns hatten, wurde dadurch erbracht, dass es uns gelang, nachdem wir mittelst des Plattenverfahrens uns in den Besitz von Reinculturen dieser in den Organen der gestorbenen Impfthiere vorhandenen Bacterienart gesetzt hatten, durch Verimpfung dieser ausserhalb des Körpers fortgezüchteten Reinculturen die gleiche Krankheit bei Kaninchen und Hühnern zu erzeugen.

Die Bacterien präsentirten sich in den aus den Organen der gestorbenen Thiere angefertigten, theils mit Gentianaviolett, theils mit Fuchsin gefärbten Ausstrichpräparaten als kleine, verhältnissmässig breite, mit abgerundeten Enden versehene Stäbchen von schwankender Länge.

Die kürzesten, besonders bei acutem Verlaufe beobachteten, näherten sich der Kokkenform, die längeren zeigten häufig, jedoch durchaus nicht immer ein an Ausdehnung sehwankendes ungefärbtes Mittelstück, so dass 
das ganze Gebilde beim ersten Anblick wie ein Doppelcoccus, oder wie zwei neben einander liegende Kokken aussah; bei Anwendung stärkster Systeme konnte man aber an diesen Gebilden immer zwei, wenn auch schwach gefärbte, die beiden anscheinenden Kokken mit einander verbindende Leisten erkennen. Bacterien.

Schnittpräparate zeigten oft haufenweises Zusammenliegen dieser

Im hängenden Tropfen erwiesen sie sich als unbeweglich.

Die Aufnahme der genannten Farbstoffe erfolgte nicht ganz leicht. Es bedurfte immerhin einer mindestens fünf Minuten langen, bei Sehnitten noch längeren Färbung in heisser Farbestofflösung, um die Präparate deutlich zu machen. Die Färbung nach Gram führte zu negativem Ergebnisse.

In den bei Zimmertemperatur gehaltenen Fleischpeptongelatine-Platten waren ihre Colonieen gewöhnlich am Anfang des dritten Tages soweit entwickelt, dass die Originalplatte staubförmige Trübung und unter dem. Mikroskop runde, später hin und wieder gebuchtete, winzig kleine, gelbliche, feingranulirte Colonieen aufwies.

Auch in der zweiten und dritten Verdünnungsplatte ging ihre Grösse selbst nach Tagen nie über höchstens $1 / 2 \mathrm{~mm}$ Durchmesser hinaus. Hier besonders, wo die einzelnen Colonieen weiter von einander entfernt waren, erhielten sie am 4. bis 5. Tage unter Zunabme der gelben Färbung eine eigenthümliche Zeichnung in Form von concentrischen Ringen, wie wir sie bisher nur an den Colonieen eines zufällig in unsere Platten gerathenen, schr schlanken und kleinen, nicht pathogenen Bacillus beobachtet haben. Bei Lampenlicht zeigte die getrübte Originalplatte deutliches Irisiren.

Immer war im Gegensatz zu der eben erwähnten schlanken Stäbchenart das Wachsthum der an der Oberfläche gelegenen Colonieen ein kümmerlicheres, als der in der Tiefe gelegenen.

In alkalischer Bouillon verursachten sie bei Bruttemperatur schon nach 24 Stunden deutliche Trübung.

Die in Fleischpeptongelatine und -Agar angelegten Stichculturen wiesen bei Zimmertemperatur, bezw. bei Brutwärme am 3. Tage resp. nach 24 Stunden eine feingranulirte, weissliche Färbung zunächst des unteren, später auch des oberen Theiles des Stichcanales auf.

Nach einigen Tagen wurde diese Trübung gleichmässiger, und bildete sich um die Einstichstelle ein grauer, durchscheinender, trockener, auf Agar mehr weissgrau gefärbter Wall, der jedoch immer eng begrenzt blieb.

Eine Verflüssigung der Gelatine wurde nie beobachtet. Aeltere Gelatine- bezw. Agarculturen wiesen in Ausstrichpräparaten neben den oben beschriebenen Formen, unter denen die mit Hohlraum versehenen vor- 
wiegend waren, noch solide, zum Theil geschwungene Fäden von der Breite der übrigen Bacterien auf.

Aus dieser Schilderung geht auf das Deutlichste die Identität unserer Bacterie mit der als Erreger der Schweinesenche von Löffler und Schütz beschriebenen hervor.

Nachdem wir einmal mit den morphologischen und tinctoriellen Eigenschaften der fraglichen Bacterien vertraut geworden waren, wurde uns.der directe Nachweis derselben in den Organen der erkrankten Schweine, der uns Anfangs nicht recht gelingen wollte, nicht mehr schwer. Wir fanden diese Bacterien nunmehr sowohl in den Ausstrich- wie in den Schnittpräparaten wieder, welche wir von den Organen der erkrankten Schweine anlegten; auch gelang es, nachdem wir die im Anfang zum Theil angewandte, unvollkommen neutralisirte Fleischpeptongelatine mit alkalischer vertauscht hatten, aus dem Gewebssaft der erkrankten Lungen der betreffenden Schweine, besonders aber aus dem Bronchialschleime derselben dieselbe Bacterienart herauszuzüchten, welche bei weiterer Verimpfung auf Kaninchen und Hübner dieselben pathogenen Eigenschaften zeigten. Nur in wenigen Fällen waren auf bisher nicht erklärte Weise ihre pathogenen Eigenschaften verloren gegangen.

Während die Vertheilung der Bacterien. in den Organen und dem Blute der geimpften Kaninchen und Hühner eine im Grossen und Ganzen gleichmässige war, ergaben diese letzten Untersuchungen, dass sie in jedem einzelnen Falle bei den Schweinen am zahlreichsten in dem glasigen, zähen Bronchialschleim vorhanden waren, welcher die zu den erkrankten Lungenpartieen führenden Bronchien erfüllte.

Weniger zahlreich fanden wir sie fast durchweg in den verkästen Lungentheilen und den verkästen Bronchialdrüsen, sehr spärlich oder gar nicht in den grauroth hepatisirten Lungentheilen sowie in der Milz und Leber.

Sehr zahlreich wurden sie ferner in der geschwellten Leistendrüse des Schwein VI vorgefunden.

Wenn nun noch nachgewiesen werden konnte, dass der von uns in den Organen der erkrankten Schweine in der obigen Vertheilung vorgefundene Organismus nicht bloss auf Kaninchen und Hühner, sondern auch auf Schweine, und zwar in der von uns an den Krzanowitzer Schweinen bèobachteten Weise pathogen wirkte, so war damit festgestellt, dass wir in ihm in der That den Erreger der betreffenden Schweinekrankheit vor uns hatten, ja wir konnten in Anbetracht der in den Organen der Krzanowitzer Schweine beobachteten eigenthümlichen Vertheilung der fraglichen Bacterien nicht mehr darüber im Zweifel sein, dass eine Aufnahme des 
Krankheitserregers in allen Fällen auf dem Wege der Respirationsorgane stattgefunden hatte.

In der That gelang uns dieser Nachweis, wie die VI. Versuchsreihe zeigt, vollkommen durch Injection einer von einer Plattencultur stammenden Bouillencultur in die Lungen des Impfschwein 1 von der Brustwand aus. Dass der Verlauf der Impflirankheit ein bedeutend rapiderer als, bei natürlicher Infection war, dürfte sich zur Genüge aus der Verwendung einer grösseren Menge des infectiösen Materials, sowie ans der Begünstjgung des Eintrittes einer Allgemeininfection durch den bei der Impfung gesetzten blutigen Lingriff erklären. Beweisend war jedenfalls das Vorhandensein einer graurothen Hepatisation der Lungen, welche sich in nichts, auch in dem bacteriologischen Befunde nicht, von der in den Anfangsstadien der Krankheit an den Krzanowitzer Schweinen beobachteten unterschied.

Besonderer Berücksichtigung bedürfen noch die Schweine VI, XIV und IL insofern, als bei ihmen neben den gewöhnlichen Veränderungen in den Lungen noch an anderen Körperstellen krankhafte Veränderungen vorhanden waren; und zwar bei Schwein VI Hautgeschwüre und ein subcutaner Abscess mit Schwellung der nächstgelegenen Lymphdrïsen, bei Schwein XIV Hautgeschwüre, bei Schwein IL eine furtlaufende Reihe käsiger Cysten, von der Castrationsstelle beginnend, dem Verlaufe der Samenstränge und später dem des Urachus subperitoneal folgend, bis zum Nabel in die Höhe reichend. Nur bezüglich des Schwein VI wurde der Nachweis erbracht, dass diese ausserbalb des Brustraumes gelegenen Veränderungen ebenfalls als eine Folge der pathogenen Wirkung unserer Bacterie zu betrachten waren, insofern, als wir in der den Hautgeschwüren nächstgelegenen, geschwellten Leistendrüse das Vorhandensein unserer Bacterien mikroskopisch und auf dem Wege der Züchtung darthaten. Die am Schwein IL vorgefundenen Käsecysten können dagegen mit der in Rede stehenden Krankheit nicht ohne Weiteres in ursächlichen Zusammenhang gebracht werden, da die aus dem Cystenkäse einzig heraus gezüchtete Bacterienart sich von unseren ovoiden Bacterien durch ihr Wachsthum und den Mangel an entsprechenden pathogenen Eigenschaften scharf unterschied.

Die Deutung des complicirten Befundes bei Schwein VI lässt bezüglich seiner Entstehung drei Möglichkeiten zu; entweder sind die krankhaften Veränderungen in den Lungen die Folge einer Hantinfection, oder die Hautgeschwüre die Folge einer von den Respirationsorganen aus stattgehabten Infection, oder es hat endlich eine Doppelinfection stattgefunden, nämlich nicht nur von den Respirationsorganen, sondern auch von der rerletzten Haut aus. 
Die Möglichkeit der Uebertragung der Schweineseuche auf subcutanem Wege wurde durch unsere Versuche allerdings nur in Bezug auf Hühner, Kaninchen und, wie wir hervorheben", auch in Bezug auf Kälber dargethan.

Schweinen gegenüber haben wir nach dieser Richtung hin nur einen einzigen Versuch, und zwar den mit Impfschwein 2 vorgenommen. Das -Ergebniss desselben war leider kein absolut befriedigendes, insofern, als das Thier nicht zu Grunde ging, und es uns, nachdem es abgeschlachtet war, nicht gelang, die ihm eingeimpfte Schweineseuchebacterie aus der Impfstelle oder seinen Organen heraus zu züchten.

Immerhin spricht der Umstand, dass das vorher gesunde Thier im Anschluss an die subcutane Impfung eine specifische Reaction an der Impfstelle, Bauchfellentzündung und später krankhafte Veränderungen der Gelenke zeigte, sehr lebhaft dafür, dass ein ursächlicher Zusammenhang zwischen der Impfung mit den Schweineseuchebacterien und den geschilderten krankhaften Veränderungen s. Z. bestanden hat, und dass wir es also hier mit einem ausgeheilten Fall subcutan übertragener Schweineseuche zu thun hatten.

Weitere Versuche über das Verhalten der Schweineseuchebacterien gegenüber verschiedenen Thiergattungen bei Anwendung verschiedener Infectionsmethoden behalten wir uns vor.

Es galt nunmehr, das Vehikel festzustellen, mittelst dessen die Infectionsträger in den Körper der erkrankten Thiere gedrungen waren.

Die Thatsache, dass die Schweineseuche in Epidemieen bisher nur in Molkereien beobachtet worden ist, veranlasste uns, auf Anregung des Königl. Departementsthierarztes Schilling, unser Augenmerk auf die in der Molkerei verfütterte Milch zu richten.

Es werden in der Krzanowitzer Molkerei täglich 2200 bis 2500 Liter Rohmilch, die von neun Dominien geliefert werden, durch Centrifugeu verarbeitet, und zwar wird täglich zweimal separirt. Die Rohmilch wird in ein blechernes Sammelbassin mittelst Kübeln geschüttet, hier durch Dampf auf $20^{\circ}$ R. erwärmt und alsdann in die Separatoren geleitet. Die Magermilch gelangt von da in Kübel und wird in einen hölzernen Bottich getragen, bei kaltem Wetter wiederum auf $20^{\circ}$ erwärmt und möglichst frisch verfüttert, indem sie mittelst Kübeln in die Ställe befördert wird. In den gemeinschaftlichen Trog des Stall 1 gelangt diese Milch mittelst eines aussen angebrachten Eingusses.

Die Ställe sind massiv; nur der Strassenstall 5 und 6 ist in Holz gefügt. Sämmtliche Fussböden sind aus cementirten Klinkern hergestellt. Die Tröge bestehen aus Sandstein, in Stall 5 und 6 ans Holz. In den Kobenställen 2, 3 und 4 besitzt jeder Koben eine Krippe für sich. 
Stall 5 und 6 besitzen dagegen ebenfalls gemeinschaftliche Futtertröge.

Das Futter besteht meist aus Magermilch; ausnahmswëise wird auch Buttermilch verfüttert.

Die Reaction der in den Trögen befindlichen Futtermilch ist Anfangs eine schwach saure.

Die Fütterung ist sehr reichlich, und es bleiben immer nach jeder Fütterung auf Stunden Rückstände in den Trögen zurück, welche bald stark sauer reagiren.

Am 18. December 1888 wurde aus der gemeinschaftlichen Krippe des inficirten Stalles Nr. 1 mehrere Stunden nach der Fütterung, nachdem in der Krippe gründlich gerührt worden war, eine Flasche rückständiger Magermilch entrommen.

In den von derselben angefertigten, durch Aether entfetteten Ausstrichpräparaten fanden wir unter anderen auch ovoide Bacterien, welche in Grösse und Form von den Löffler-Schütz'schen Schweineseuchenbacterien nicht zu unterscheiden waren. Noch zahlreicher fander sie sich in dem Bodensatze dieser Magermilch.

\section{Versuchsreihe.}

Diese Milch wurde tüchtig aufgeschüttelt und davon den Kaninchen 40 und 41 je 1/4 Pravaz'sche Spritze unter die Rückenhaut gespritzt.

Darauf liessen wir die Milch absetzen, und spritzten am 18. December einen Theil des Bodensatzes in der gleichen Weise den Kaninchen 42 und 43 unter die Rückenhaut. Kaninchen 42 und 43 waren schon am 19. December todt.

Sectionsbefund von Kaninchen 42 und 43: An der Impfstelle eiterige Lymphangitis, rechte Bugdrüse markig geschwollen, Milzschwellung mit weicher Pulpa, trübe Schwellung der Leber und Nieren; bei Kaninchen 42 zahlreiche embolisehe Herde in der Leber, welche bei Kaninchen 43 fehlen.

In den Ausstrichpräparaten des Gewebssaftes der inneren Organe, besonders der Leber, der Nieren, des Blutes, der Lymphdrüsen unendlich zahlreich und ausschliesslich ovoide Bacterien, die durchaus die Form der Löffler-Schütz'schen Schweineseuchenbacterien besassen.

Mit einem Stückehen Milz des Kaninchens 43 wurde am 19. December am Rücken geimpft: Kaninchen 45 .

Ferner wurde 1/2 Pravaz'sche Spritze mit dem Herzblut des Kaninchen 43 beschickter, sterilisirter, alkalischer Brühe am 19. December dem Kaninchen 46 direct in die Luftröhre gespritzt. 
Des Weiteren wurde am selben Tage aus dem Gewebssaft der Leber des Kaninchen 43 eine Fleischpeptongelatine-Stichcultur angelegt, in welcher am 26. December eine Reincultur der Löffler-Schütz'schen Schweineseuchebacterien gewachsen war.

Endlich wurden am 19. December aus dem Herzblut des Kaninchen 43 drei Fleischpeptongelatine-Platten angelegt, welche am 26. December ebenfalls entsprechend zahlreiche Colonieen von der den erwähnten Bacterien zukommenden Form gewachsen zeigten. Ausstrichpräparate einzelner dieser Colonieen enthielten lediglich die erwähnten Bacterien mit allen den früher geschilderten. Formeneigenthümlichkeiten.

Kaninchen 46 war am 20. December, Kaninchen 45 am 21. December gestorben.

Sectionsbefund von Kaninchen 46: Unterhautbindegewebe um die Einstichstelle am Halse ödematös geschwellt und von kleinen, theils hämorrhagischen, theils eiterigen Herden durchsetzt. Schleimhaut der Luftröhre geschwellt und mit hämorrhagischen Herden durchsetzt; Luftröhre blutigen Schleim enthaltend. Lungen unvollständig zusammengefallen und grauroth hepatisirt; die Leber enthält zahlreiche embolische Herde der früher beschriebenen Form; starke Milzschwellung; trübe Schwellung der Nieren.

Ausstrichpräparate des Gewebssaftes des ödematösen Bindegewebes zeigen anscheinend zwei Bacterienarten, einen grösseren klobigen Bacillus und ferner die Löffler-Schütz'schen Schweineseuchenbacterien, letztere in bedentend überwiegender Anzahl. Den gleichen Befund, nur mit noch bedeutenderem Ueberwiegen der Schweinesenchenbacterien zeigen die aus dem Gewebssaft der Lymphdrüsen, Milz, Leber und Nieren und dem Blute angefertigten Ausstrichpriparate.

Sectionsbefund des Kaninchen 45: Unterhautbindegewebe der Impfstelle ödematös, zahlreiche embolische Herde in der Leber, geringe Milzschwellung.

In den Ausstrichpräparaten der Impjfstelle, des Gewebssaftes der inneren Organe, des Herzblutes sehr zahlreich und ausschliesslich die LöfflerSchütz'schen Bacterien.

Am 20. December wurden angelegt:

1. Von dem Gewebssaft der Leber des Kaninchen 46 ein Fleischpeptonagarstich, welcher am 26. December die Schweineseuchenbacterien in charakteristischer Form gewachsen zeigte.

2. Aus dem Herzblut des Kaninchen 46 drei FleischpeptongelatinePlatten, welche am 26. December eine entsprechende Anzahl der Schweineseuchenbacterien-Colonieen aufwiesen.

Von einer dieser Platten wurde am 26. December eine isolirte Colonie gefischt und damit ein Gläschen sterilisirter, alkalischer Bouillon inficirt, 
welche am 28. December bei Brutwärme sich getrübt hatte und eine Reincultur der Schweineseuchebacterien enthielt.

Von dieser Bouillon wurde am 28. December eine Pravaz'sche Spritze voll vom Intercostalraum aus dem Impfschwein 4 in die rechte Lunge gespritzt.

Am 30. December war Impfschwein 4 traurig, athmete schwer unter röchelnden Geräuschen; Druckschmerz an der Brustwand, gespannter Gang, Durchfall.

Zur Beschleunigung des Verlaufes wurde am 30. December der Rest derselben Brühecultur dem Impfschwein 4 in die linke Lunge gespritzt.

Trotzdem war das Schwein am 2. Januar 1889 ziemlich munter. Es wurde deshalb noch ein Theil der in der Originalplatte (von Kaninchen 43 stammend) enthaltenen Gelatine in erwärmter steriler, alkalischer Bouillon geschmolzen und diese Brühe nun am 2. Januar 1889 rom Intercostalraum aus in die rechte Lunge gespritzt.

Am 15. Januar 1889 war Impfschwein 4 gestorben.

Sectionsbefund: Keine Hautrerfärbungen. Bindegewebe um den Stichcanal fingerdick, ebenso wie die Musculatur daselbst, ödematös durehtränkt. Rechte Axillar-Hals- und Submaxillardrüse markig geschwellt. An den Einstichstellen rechts und links am Thorax je eine bohnengrosse, eiterige Geschwulst. An diesen. Stellen sind die Lungen mit der Brustwand verwachsen. Graurothe Hepatisation beider Vorderlappen. Hinterlappen an den Einstichstellen je einen Käseherd enthaltend, der auf eine Strecke hin von grauroth hepatisirtem Lungengewebe umgeben ist. Bronchialdrüsen markig geschwellt, mit käsigen Herden durchsetzt, die zu den hepatisirten Stellen führenden Bronchien mit glasigem, zähem, trübgelblichem Schleim erfüllt. Milz nicht geschwellt, Magen-Darmcanal normal.

Ausstrichpräparate zeigten die Löffler-Sch ütz'schen Schweineseuchebacterien in dem ödematösen Unterhautbindegewebe und in der Geschwulst um die Einstichcanäle, sowie im glasigen Bronchialschleim sehr zahlreich, in den verkästen Partieen der Lungen etwas weniger zahlreich, in der Milz und Leber vereinzelt vorhanden. Im Blute wurden keine gefunden.

Von Impfschwein 4 wurden am 15. Januar 1889 angelegt:

1. Von einer der verkästen Partieen der Bronchialdrüsen:

a) drei Fleischpeptongelatine-Platten, welche am 20. Januar bereits die charakteristischen Colonieen der Löffler-Sch ütz'schen Bacterien in entsprechender Anzahl aufwiesen;

b) ein Gelatinestich, welcher am 18. Januar eine Reincultur der gleichen Bacterien gewachsen zeigte.

2. Vom Gewebssaft der Milz ein Gelatinestich mit dem gleichen positiven Resultate. 
Von dem Herzblut des Kaninchen 42 wurden'am 19. December drei Fleischpeptongelatine-Platten, von dem Gewebssaft der Leber des Kaninchen 42 ein Gelatinestich angelegt, beides mit demselben positiven Resultat, wie oben beschrieben.

Kaninchen 40 und 41 waren erst am 21. December gestorben.

Sectionsbefund: Oedematöse Durchtränkung des Unterhautbindegewebes an der Impfstelle, zahlreiche Embolien in der Leber, sonst wie bei den anderen Kaninchen.

Ausstrichpräparate der Impfstelle des Herzblutes und des Gewebssaftes der inneren Organe zeigen sehr zahlreich die Löffler-Schütz'schen Bacterien.

Am 27. December wurden, nachdem der Eigenthümer des inficirten Gehöftes zur Verfütterung einer einmaligen, grösseren Menge von Magermilch veranlasst worden war, drei Stunden nacher bei noch ziemlich gefüllter Krippe entnommen:

1. eine Flasche Futtermilch aus der Krippe des Stalles 5 und 6 ,

2. eine Flasche Futtermilch aus der Krippe des Stalles 1.

Ausstrichpräparate dieser zwei Milchproben erwiesen das Vorhandensein oroider Bacterien von der Art der Löffler-Schütz'schen.

\section{Versuchsreihe.}

Am 27. December wurde von der aus Krippe Stall 1 stammenden Milch eine Quantität:

1. dem Kaninchen 51 unter die Rückenhaut,

2. dem Huhn 12 unter die Hant an der rechten Brustseite gespritat,

3. von dẹm Bodensatze dieser Milch, in welchem Haufen anscheinend der Löffler-Schütz'schen Bacterien gefunden wurden, erst eine halbe Praraz'sche Spritze dem Impfschwein 3 (sechs Wochen alter Borg) mittelst Einstichs direct in die Luftröhre und dann eine grössere Quantität in die Nase gespritzt, so dass es sich verschluckte und stark hustete.

Am 6. Januar 1889 war Impfschwein 3 sehr krank, zeigte grosse Athembeschwerden, Durchfall, Schwellung der Einstichstelle am Halse, häufigen kraftlosen Husten und Temperatur von $40 \cdot 7^{\circ}$.

Am 7. Januar war der Tod eingetreten.

Sectionsbefund: Cutis über der Einstichstelle und an der Bauchgegend schwach geröthet, das subcutane Bindegewebe und die Musculatur in der Nähe der Einstichstelle ödematös durchtränkt, mit kleinen Eiterherden durchsetzt. Rechte Axillardrüse geschwellt, einen käsigen Herd enthaltend. Luft- 
röhre mit trübgelbem, glasigem, zähem Schleim gefüllt. Beide Vorderlappen und ein Theil der beiden Hauptlappen grauroth hepatisirt mit glatter Schnittfläche; innerhalb der hepatisirten Stellen zahlreiche gelbliche, käsige Herde. Die zu den hepatisirten Lungentheilen führenden Bronchien' enthalten denselben glasigen Schleim, wie die Luftröhre. Milz nicht geschwellt, Pulpa trocken, Zeichnung deutlich erkennbar, Leber braunroth, nicht vergrössert mit deutlicher Zeichnung, Nieren, Schleimhaút des Magens und Darmcanals, auch der Ileocoecalklappe normal, ebenso die Peyer'schen Plaques.

In den Ausstrichpräparaten des graugelben Bronchialschleimes, sowie in denen der das Bindegewebe an der Impfstelle durchsetzenden Eiterherde unendlich zahlreiche Löffler-Schütz'sche Bacterien. In den aus dem Gewebssaft der inneren Organe angelegten Ausstrichpräparaten konnten wir keine Bacterien nachweisen.

Es wurden ron Impfschwein 3 am 7. Januar 1889 angelegt:

1. Aus dem Bronchialschleim:

a) drei Fleischpeptongelatine-Platten, welche am 13. Januar 1889 eine entsprechende Anzahl Colonieen der Löffler-Schütz'schen Bacterien aufwiesen,

b) drei Brüheculturen, von denen zwei am 12. Januar getrübt waren und die gleichen Bacterien in weit überwiegender Zahl enthielten; die dritte war steril geblieben.

2. Aus dem Gewebssaft der Leber:

a) eine Gelatinestichcultur,

b) eine Agarstichcultur.

Beide blieben steril.

3. Aus dem Gewebssaft der Milz:

a) eine Gelatinestichcultur,

b) eine Agarstichcultur,

von denen die erstere steril blieb, die zweite in charakterischer Weise anging als Reincultur der Löffler-Schütz'schen Bacterien.

Kaninchen 51 war am 18. December todt.

Der makroskopische und mikroskopische Befund glich dem von Kaninchen 40 und 41 ; ausserdem graurothe Hepatisation der rechten Lunge.

Huhn 12 blieb gesund.

\section{Versuchsreihe.}

Am 27. December 1888 ferner wurden von der aus der Krippe des Stall 5 und 6 entnommenen Milch:

1. Kaninchen 50,

2. Huhn 11 (dieses mit dem Bodensatze) 
subcutan geimpft. Kaninchen 50 blieb gesund, Huhn 11 war am 13. Januar gestorben.

Sectionsbefund: An der Impfstelle das Unterhautzellgewebe ödematös geschwellt; an der inneren Organen nichts Auffälliges.

Der Gewebssaft des Bindegewebes der Impfstelle wies in weitaus überwiegender Zahl die Löffler'-Schütz'schen Bacterien auf; die gleichen Bacterien fanden sich, wenn auch vereinzelt, so doch ganz allein im Knochenmark, in der Leber, Milz und Lunge.

\section{Controlversuche.}

Zur Controle wurde:

1. am 31. December 1888 den Kaninchen 55 und 56 je eine Pravazspritze aus einem hiesigen, nicht inficirten Gehöft stammender Milch,

2. am 2. Januar 1889 den Kaninchen 57 and 58 je eine Pravazspritze aus der Heumos'schen Molkerei stammender Magermilch am Rücken unter die Haut gespritzt.

Kaninchen 55 blieb gesund, Kaninchen 56 starb am 13. Januar 1889, Kaninchen 57 und 58 starben am 11. Januar.

Sectionsbefund von Kaninchen 56 bis 58: Eiteriger Abscess an der Impfstelle, embolische Herde in der Leber.

In keinem der von der Impfstelle und vom Gewebssaft der inneren Organe angelegten Ausstrichpräparate konnten wir die Löffler-Schütz' schen Bacterien nachweisen. Im Gewebssaft der Leber waren unregelmässig gestaltete, sich mit Fuchsin färbende Körner und Klumpen vorhanden, die aber keinesfalls als Bacterien irgend welcher Art zu deuten waren (Gregarinen?); alle Ausstrichpräparate, die von dem Gewebssaft der übrigen Organe angelegt wurden, wiesen keine Bacterien auf.

Sämmtliche von dem Milz- und Lebersaft dieser Thiere angelegten Gelatinestiche und -Platten blieben steril.

Zur Vervollständigung dieser Versuchsreihen dienten folgende, auf das Verhalten der Schweineseuchenbacterien gegenüber von Milch, insbesondere auf ihre Wachsthumsverhältnisse in normaler, beziehungsweise saurer Milch gerichteten Versuche.

\section{Versuch.}

Am 19. sowie am 23. December wurden zwei, bezw. drei mit mehrere Stunden im Dampfkochtopf sterilisirter Milch versehene Reagensgläschen mit Reincultur der Löffler-Schütz'schen Bacterien inficirt und darauf bei Brutwärme gehalten. 
Desgleichen wurden am selben Tage drei mit sterilisirter Milch beschickte Objectträger mit den gleichen Bacterien inficirt und darauf der Brutwärme ausgesetzt.

Die durch Anfertigung von Ausstrichpräparaten am 4. Januar 1889 veranstaltete Untersuchung dieser sümmtlichen Proben liess eine Vermehrung der Bacterien vermissen.

Da. danach gewöhnliche Milch als günstiger Nährboden für die in Frage stehenden Bacterien nicht anzusehen war, beschickten wir:

\section{Versuch.}

a) Am 29. December ein Gläschen sterilisirter saurer Brühe mit einer Spur der fraglichen Bacterien. Schon am nächsten Tage zeigte die bei Bruttemperatur gehaltene Brühe deutliche Trübung und einen Gehalt an den erwähnten Bacterien in einer Anzahl, die über eine thatsächlich stattgehabte Vermehrung uns nicht im Zweifel liess.

b) Am 31. December ein mit sterilisirter Molke versehenes Reagensgläschen.

c) Am 31. December zwei mit sterilisirter Molke versehene hohle Objectträger mit Spuren der Löffler-Schütz'schen Bacterien. (Diese Molke war gewonnen worden, indem wir Milch sauer werden liessen, das Serum abgossen, dann dasselbe längere Zeit kochten und endlich filtrirten. Wir erhielten so ein vollkommen klares Filtrat von stark saurer Reaction.)

Schon am ersten, noch mehr am zweiten Tage zeigten die hängenden Tropfen sowohl, wie der Inhalt des Reagensgläschens (bei Brutwärme gehalten) deutliche Trübung und bei der mikroskopischen Untersuchung eine auf reichliche Vermehrung hindeutende Menge von Löffler-Schütz'schen Bacterien in Reincultur.

\section{Versuch.}

Das gleiche Verhalten zeigte ein mit sterilisirter Molke der aus Krippe Stall 1 stammenden Magermilch beschicktes, am 2. Januar inficirtes Reagensgläschen am folgenden Tage.

\section{Versuch.}

Am 3. Januar wurden je ein mit saurer sterilisirter Milch, resp. mit saurer sterilisirter Brühe beschicktes Gläschen durch eine aus einer Reincultur der Löffler-Schütz'schen Bacterien entnommene Spur inficirt und alsdann bei Bruttemperatur gehalten. Beide Gläschen wiesen am 6. Januar einen auf reichliche Vermehrung deutenden Gehalt der fraglichen Bacterien auf. 


\section{Versuch.}

Mehrere mit saurer Fleischpeptongelatine; resp. mit einer Gelatine, die aus der oben erwähnten sauren Molke hergestellt war, vorgenommene Züchtungsversuche bewiesen, dass diese Nährböden für die Entwickelung der Löffler-Schütz'schen Bacterien ungeeignet sind.

\section{Versuch.}

Ein am 31.December 1888 mit den Schweineseuchenbacterien inficirtes, saure Molke enthaltendes Gläschen war am 13. Januar stark getrübt und enthielt, kolbige Involutionsformen, die ihrem Aussehen nach nur wenig an ihre Stammeltern erinnerten.

Von dem Inhalt dieses Gläschens wurde am 13. Januar eine Oese zur Anlegung von drei Fleischpeptongelatine-Platten benützt.

Am 18. Januar war in diesen Platten nur eine Colonie der Schweineseuchenbacterien, allerdings aber von durchaus charakteristischen Eigenschaften, gewachsen.

Wenn die Versuche XIX bis XXIV lediglich lehren, dass normale Milch für die Schweineseuchenbacterien keinen geeigneten Nährboden abgiebt, dass dagegen die genannten Bacterien in saurer Molke, saurer Milch, ebenso wie in saurer Bouillon sich durch Tage nicht nur lebensfähig erhalten, sondern sogar vermehren können, so beanspruchen die Versuchsreihen XVI bis XVIII insofern ein besonderes Interesse, als sie Klarbeit verschafften in Bezug auf die Art und Weise der Weiterverbreitung der Krankheit in der Krzanowitzer Molkerei, wie in Molkereien überhaupt.

Obgleich die Schweineseuche ausserhalb von Molkereien häufig genug vorkommen mag, wofür die Thatsache spricht, dass unter den Treiberherden z. B. des Waldenburger Kreises s. Z. hänfig käsige Lungenentzündungen beobachtet wurden, so sind grössere Epidemieen von Schweineseuche doch bisher nur in Molkereien bekannt geworden.

Nach den Ergebnissen der Versuchsreihen XVI bis XVIII muss man annehmen, dass das der seuchenartigen Verbreitung der Krankheit in Molkereien Vorschub leistende Moment in der daselbst üblichen gemeinsamen Verfütterung von Milch liegt, und dass die von gesunden und kranken Schweinen gemeinsam benützten Tröge der Ort sind, wo die kranken Schweine den Infectionsträger deponiren, und von wo er wiederum in die Luftwege gesunder Schweine dringt.

Dass dem so ist geht, aus Folgendem hervor:

1. Nur die Verimpfung der den gemeinschaftlichen Trögen entnommenen Futterreste, nicht aber die der Nilch, welche mit den Trögen noch 
nicht in Berührung gekommen war, führte in gleicher Weise, wie die Verimpfung der Organtheile der erkrankten Schweine zur Isolirung der Schweineseuchenbacterien.

2. Die den (mit dem Seuchengehöft nicht in Berührung gelrommenen, vorher gesunden) Impfschweinen in die Luftwege gebrachten Futterreste erzeugten bei diesen das typische Bild der Schweineseuche.

Aber nicht nur der Verbreitung der Krankheit in der Herde, sondern auch der Intensität des Verlaufes der Krankheit im einzelnen Individuum scheint die erwähnte Fütterungsart Vorschub zu leisten. Wenigstens stellten wir an zwei der uns bereits in erkranktem Zustande überwiesenen Schweine (Nr. XLVII und Nr. XLVIII), welche von uns unter anderen Verhältnissen gehalten wurden, trotz der notorisch monatelangen Krankheitsdaner nur geringgradige anatomische Veränderungen fest.

Bei dem langen Verweilen der Futtermilch in den gemeinsamen Trögen haben die kranken Schweine dauernd Gelegenleit, durch die häufigen Hustenstösse beim Fressen den nach unseren Untersuchungen an den Schweineseuchenbacterien besonders reichen Bronchialschleim in die Tröge zu entleeren. Hier gerathen die Infectionsträger in die Futterreste und gelangen mit diesen in die Nase und Luftwege der gesunden Schweine, und zwar um so leichter, als Schweine bekanntlich wïhrend des gierigen Fressens die Nase tief in's Futter einzutauchen und sich hïufig . zu verschlucken pflegen.

Je weniger Schweine ein und denselben Trog benützen, desto langsamer wird naturgemäss die Krankheit sich verbreiten, wie ja auch zu Krranowitz die Verbreitung der Krankheit in den Kobenstïllen eine langsamere war, wie in Stall 1, 5 und 6.

Es ist dies unseres Frachtens ein nicht unwichtiger Fingerzeig für die Prophylaxe insofern, als es sich, da die gemeinsame Fütterung in Molkereien kaum ganz zu umgehen ist, für Molkereibesitzer empfehlen würde, neu angelaufte Schweine, bevor sie dem übrigen Bestande einverleibt werden, erst für längere Zeit in kleineren, mit Einzeltrögen versehenen Ställen unter Quarantaine zu halten.

Ist die Krankheit in Molkereien einmal ausgebrochen, so ist die Tilgung eine sehr schwierige. Es spricht dafür die Ausbreitung der Krankheit auf alle Ställe des Seuchengehöftes und besonders die von uns beobachtete Thatsache, dass die Krankheit in Stall 5 und 6 im Februar 1889 von Neuem wieder ausbrach trotz der isolirten Lage desselben, und trotzdem eine sehr gründliche Desinfection vorangegangen war. 
Ohne Evacuirung aller kranken und verdächtigen Thiere dürfte die Tilgung in Molkereien überhaupt nicht zu erreichen sein.

Selbst die in derartigen Anstalten aus ökonomischen Rücksichten empfehlenswerth erscheinende Belegung der inficirten Ställe mit Kälbern ist nach dem Ergebniss der VersuchsreiheXIV in hohem Grade bedenklich, und sind nach dieser Richtung hin weitere Versuche im Interesse der Gesetzgebung wünschenswerth.

Nicht unerwähnt möchten wir endlich lassen, dass, so lange nicht die Immunität des Menschen gegenüber den Schweineseuchenbacterien sicher nachgewiesen ist, die aus unseren Versuchen hervorgehende pathogene Wirkung der Schweineseuchenbacterien gegenüber sehr verschiedenen Thiergattungen eine solche auch dem Menschen gegenüber befürchten lässt, und dass deshalb eine besonders vorsichtige Handhabung der lileischsehau wach dieser Richtung geboten ist. 
Schoma der

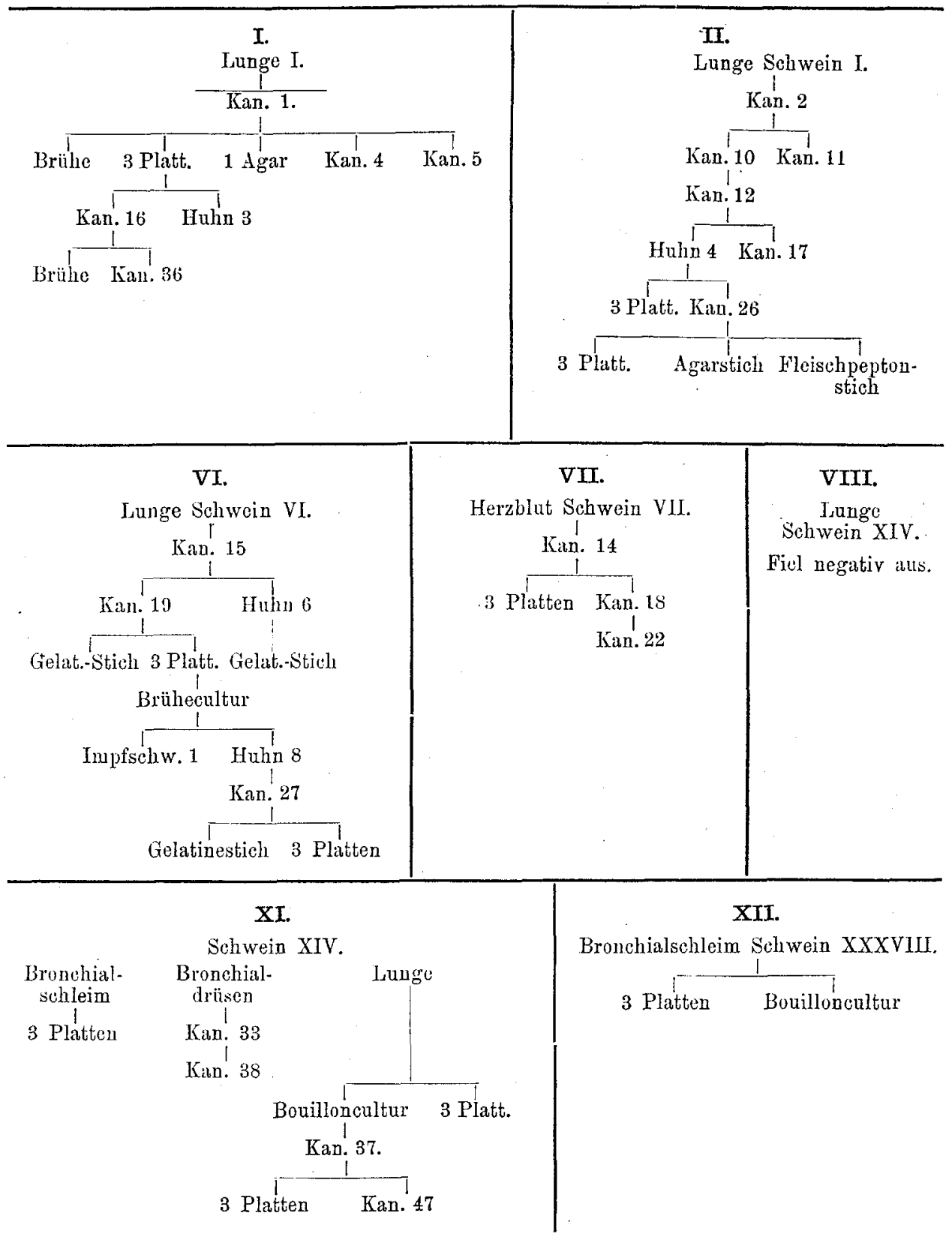




\section{Versuchsreihen.}

\section{Organe.}

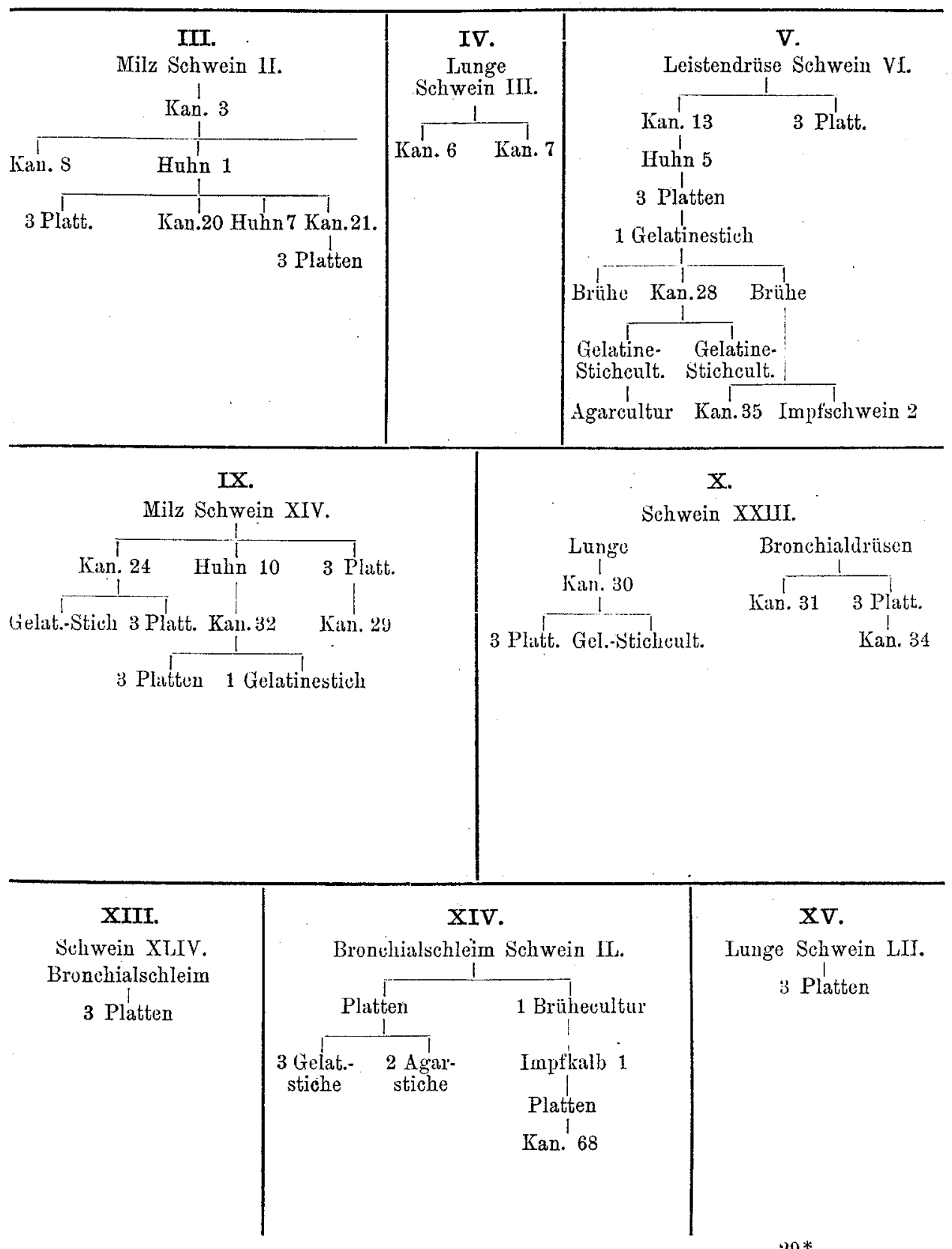


452 Bueisch und Fiedeler: Beitk. z. Kenntwiss D. Schweineseuche.

Schema der Versuchsreihen.

II. Milch.

$\mathrm{XVI}$.

Milch Stall 1.

Kan, 40 Kan. 41

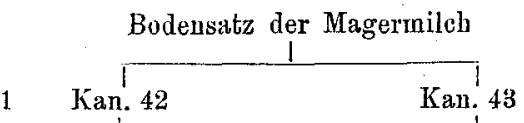

3 Platten Gel.-Stich Kan. 45 Kan. 46 Gelatinestich 3 Platt.

Gelatinestich 3 Platten

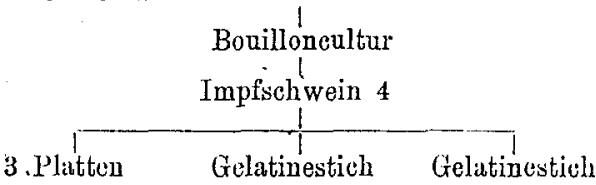

XVII.

Milch Stakl I

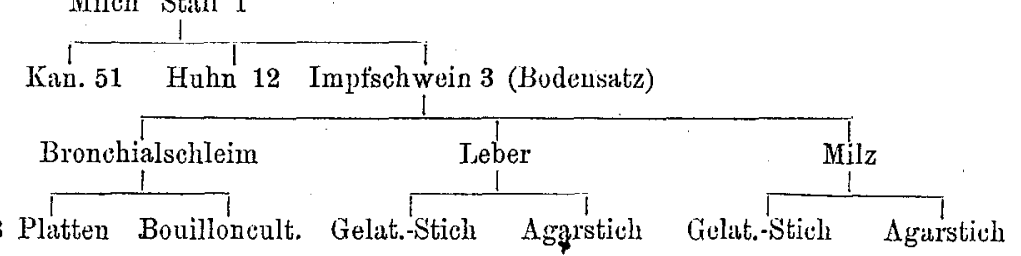

XVIII.

Milch Stall 5 und 6.

Kian. $50 \quad$ Huhn 11 (Bodensatz)

